\title{
Het beroependomein van opleidingen
}

Citation for published version (APA):

Borghans, L., de Grip, A., Smits, W., \& Zuurbier, H. (1997). Het beroependomein van opleidingen.

Researchcentrum voor Onderwijs en Arbeidsmarkt, Faculteit der Economische Wetenschappen. ROA Reports No. 2 https://doi.org/10.26481/umarep.1997002

Document status and date:

Published: 01/01/1997

DOI:

10.26481/umarep.1997002

Document Version:

Publisher's PDF, also known as Version of record

\section{Please check the document version of this publication:}

- A submitted manuscript is the version of the article upon submission and before peer-review. There can be important differences between the submitted version and the official published version of record.

People interested in the research are advised to contact the author for the final version of the publication, or visit the DOI to the publisher's website.

- The final author version and the galley proof are versions of the publication after peer review.

- The final published version features the final layout of the paper including the volume, issue and page numbers.

Link to publication

\footnotetext{
General rights rights.

- You may freely distribute the URL identifying the publication in the public portal. please follow below link for the End User Agreement:

www.umlib.nl/taverne-license

Take down policy

If you believe that this document breaches copyright please contact us at:

repository@maastrichtuniversity.nl

providing details and we will investigate your claim.
}

Copyright and moral rights for the publications made accessible in the public portal are retained by the authors and/or other copyright owners and it is a condition of accessing publications that users recognise and abide by the legal requirements associated with these

- Users may download and print one copy of any publication from the public portal for the purpose of private study or research.

- You may not further distribute the material or use it for any profit-making activity or commercial gain

If the publication is distributed under the terms of Article $25 \mathrm{fa}$ of the Dutch Copyright Act, indicated by the "Taverne" license above, 


\title{
Het beroependomein van opleidingen
}

ROA-R-1997/2

\author{
Lex Borghans \\ Andries de Grip \\ Wendy Smits \\ Hubert Zuurbier
}

Researchcentrum voor Onderwijs en Arbeidsmarkt

Faculteit der Economische Wetenschappen en Bedrijfskunde Universiteit Maastricht

Maastricht, februari 1997 
ISBN 90-5321-201-9

SEC96.720 


\section{Inhoud}

Bladzijde

1 Inleiding 1

2 Uitgangspunten $\quad 5$

2.1 Inleiding 5

2.2 Arbeidsmarktpositie versus inhoud van het werk 5

$\begin{array}{ll}2.3 \text { Enkele relevante dimensies } & 6\end{array}$

$\begin{array}{ll}2.4 \text { Methodes voor het typeren van beroepen } & 7\end{array}$

3 Typeringen van beroepsgroepen $\quad 11$

$\begin{array}{ll}3.1 \text { Inleiding } & 11\end{array}$

$\begin{array}{ll}3.2 \text { Typering beroepsniveau } & 12\end{array}$

$\begin{array}{ll}\text { 3.3 Typering beroepsterrein } & 14\end{array}$

$\begin{array}{ll}3.4 \text { Typering vereiste vaardigheden } & 17\end{array}$

$\begin{array}{ll}3.5 \text { Typering aard van de werkzaamheden } & 20\end{array}$

$\begin{array}{ll}3.6 \text { Typering kwaliteit van het werk } & 20\end{array}$

4 Typering van het beroependomein per opleidingstype 27

$\begin{array}{ll}4.1 \text { Inleiding } & 27\end{array}$

4.2 Beroepsniveau $\quad 27$

$\begin{array}{ll}4.3 \text { Beroepsterrein } & 28\end{array}$

$\begin{array}{ll}4.4 \text { Vereiste vaardigheden } & 31\end{array}$

4.5 Aard van de werkzaamheden $\quad 31$

$\begin{array}{ll}4.6 \text { Kwaliteit van het werk } & 35\end{array}$

5 Enkele combinaties van typeringen $\quad 39$

$\begin{array}{ll}5.1 \text { Inleiding } & 39\end{array}$

5.2 Fysieke belasting op vakspecifiek en uitwijksegment bij lager
en middelbaar opgeleiden

$\begin{aligned} & 5.3 \text { Vereiste vaardigheden op vakspecifiek en uitwijksegment } \\ & \text { bij hoger opgeleiden }\end{aligned}$
40

6 Toepassingsmogelijkheden binnen het informatiesysteem
onderwijs-arbeidsmarkt

$\begin{array}{ll}\text { Literatuur } & 53\end{array}$

Bijlage A Typeringen van werksoorten SBC'92 55 

$\ldots$ 


\section{Inleiding}

Het Informatiesysteem Onderwijs-Arbeidsmarkt van het Researchcentrum voor Onderwijs en Arbeidsmarkt (ROA) heeft als doel de arbeidsmarkt transparant te maken voor belanghebbenden bij investeringen in onderwijs en scholing. Dit betreft leerlingen die met hun studiekeuze voor een belangrijk deel hun toekomstige mogelijkheden op de arbeidsmarkt vastleggen, de overheid en scholen, die veelal financieel en inhoudelijk betrokken zijn bij onderwijsinvesteringen, de arbeidsorganisaties aan de vraagkant van de arbeidsmarkt, de betrokkenen bij het arbeidsmarktbeleid en de sociale zekerheid en de intermediairs op de arbeidsmarkt die zich voor de taak gesteld zien vraag en aanbod zo goed mogelijk bij elkaar te brengen. Door het verschaffen van goede informatie over de actuele situatie en de verwachte toekomstige ontwikkelingen op de arbeidsmarkt kunnen deze betrokkenen beter onderbouwd hun beslissingen nemen, waardoor een verbeterde aansluiting tussen onderwijs en arbeidsmarkt verwacht kan worden (Zie Borghans, 1993 en Heijke, 1993).

Centraal in het informatiesysteem staat de Indicator Toekomstige Arbeidsmarktsituatie (ITA) die op basis van vraag- en aanbodontwikkelingen per opleidingstype aangeeft of het perspectief van een opleiding op de middellange-termijn goed, redelijk, matig of slecht zal zijn. Als het aanbod de vraag duidelijk overtreft kan verwacht worden dat met name de nieuwkomers met deze opleidingsachtergrond meer moeite zullen ondervinden met het vinden van werk, en wellicht genoegen moeten nemen met een minder gunstig salaris, een baan buiten het eigen vakgebied of een functie beneden het genoten opleidingsniveau.

Naast de informatie van de verwachte arbeidsmarktperspectieven, kan echter ook informatie over de aard of inhoud van het werk van belang zijn voor investeringsbeslissingen. Personen met eenzelfde opleidingsachtergrond blijken veelal in uiteenlopende functies terecht te komen. Dit blijkt bijvoorbeeld uit de indicator voor uitwijkmogelijkheden die laat zien dat het merendeel van de opleidingen een beroependomein kent dat meerdere functies beslaat (ROA, 1995a, b). Uitzonderingen zijn opleidingen zoals WO geneeskunde, waarvoor duidelijk één beroepsgroep domineert. Betrokkenen zullen daardoor doorgaans ook een duidelijk beeld hebben van de aard van het werk dat bij deze opleiding hoort. Bij de meeste opleidingstypen is dit beroependomein echter meer divers, en is derhalve aanvullende informatie over de aard van de werkzaamheden van belang voor de beoogde transparantie van de arbeidsmarkt.

In de eerste plaats geldt dit uiteraard voor leerlingen die voor hun studiekeuze staan. Hoewel veel leerlingen in toenemende mate een goed arbeidsmarktperspectief een belangrijke factor vinden bij hun studiekeuze (zie bijvoorbeeld Weerdenburg, 1985 en Oosterbeek en Webbink, 1995) zullen ook persoonlijke voorkeuren en 
capaciteiten van groot belang zijn bij de studiekeuze. Voor deze aspecten is een goed inzicht in de aard van het werk dat men zal gaan verrichten cruciaal.

In de tweede plaats zullen ook degenen die betrokken zijn bij de curriculumplanning baat hebben bij meer inhoudelijke informatie over de arbeidsmarkt. Zeker nu de kwalificatiestructuur, zoals in de WEB, ook wettelijk nadrukkelijk gekoppeld wordt aan de arbeidspraktijk, is informatie over eventuele recente en toekomstige verschuivingen in het beroependomein van de schoolverlaters van een bepaalde opleiding van groot belang.

Als derde voorbeeld van de gebruikswaarde van informatie over de aard van het werk dat mensen met een bepaalde opleidingsachtergrond kunnen bereiken kan gewezen worden op arbeidsmarktbeleid gericht op de herintrede van 'arbeidsongeschikten'. Het beleid is er de laatste jaren immers op gericht om na te gaan of personen die voor bepaalde functies ongeschikt zijn, wel in andere functies ingezet kunnen worden. Ook om een dergelijk beleid te ondersteunen dient informatie over de aard van bepaalde werkzaamheden gekoppeld te worden aan informatie over de ontwikkelingen in de werkgelegenheid in de desbetreffende functies. Ook voor een preventief beleid gericht op het verkleinen van de instroom in de arbeidsongeschiktheidsregelingen, zou nadere informatie over de aard van de werkzaamheden in het beroepsdomein van de diverse opleidingstypen van groot belang kunnen zijn.

Meer inzicht in het karakter van het beroependomein van opleidingstypen kan binnen het informatiesysteem zowel een rol spelen bij de typering van de actuele situatie op de arbeidsmarkt, als bij de typering van de toekomstige ontwikkelingen. Ten aanzien van de toekomstige ontwikkelingen kan er in de eerste plaats sprake zijn van autonome verschuivingen in het beroependomein, zonder dat deze direct invloed hebben op het arbeidsmarktperspectief. Hierbij kan bijvoorbeeld gedacht worden aan een toename van het fysiek zwaar werk bij de beroepsmogelijkheden van een bepaald opleidingstype door verschuivingen aan de vraagkant van de arbeidsmarkt. Dergelijke informatie verhoogt vanzelfsprekend de waarde van de prognoses van de werkgelegenheids-ontwikkelingen naar beroep en opleiding. In de tweede plaats kunnen verschuivende vraag-aanbod-verhoudingen er de oorzaak van zijn dat de aard van het werk gaat veranderen. Als schoolverlaters van een bepaalde opleiding bijvoorbeeld moeite ondervinden bij het zoeken van werk, zullen zij wellicht uit moeten wijken naar functies die tot dan toe nauwelijks vervuld werden door mensen met deze opleidingsachtergrond (Zie Wieling en Borghans, 1995). Ook hierdoor kan de aard van de werkzaamheden zich wijzigen. De typering van de verwachte verschuiving in de aard van het werk geeft in dat geval een beter beeld van de consequenties van de voorspelde arbeidsmarktperspectieven. 
Dit rapport heeft als doel na te gaan op welke wijze het beroependomein van opleidingen getypeerd kan worden in een aantal dimensies die van belang zijn voor de betrokkenen. Er bestaat uiteraard reeds een omvangrijke literatuur op het gebied van beroepenbeschrijvingen ${ }^{1}$. In dit rapport ligt het accent echter niet bij het typeren van beroepen, maar wordt onderzocht op welke wijze dergelijke informatie gebruikt kon worden om de arbeidsmarkt van een bepaalde opleiding beter in kaart te kunnen brengen. De koppeling van beroepskenmerken met de arbeidsmarktgegevens in het Informatiesysteem Onderwijs-Arbeidsmarkt staat derhalve centraal. Allereerst $\mathrm{zal}$ in hoofdstuk 2 een overzicht worden gegeven van een aantal belangrijke dimensies van het werk en wordt nagegaan op welke wijze beroepen aan de hand van deze dimensies getypeerd kunnen worden. Op grond van de mogelijkheden die thans voorhanden zijn wordt vervolgens een keuze gemaakt voor een aantal dimensies die in dit rapport nader geanalyseerd zullen worden. Daarbij zal in belangrijke mate worden aangesloten bij de mogelijkheden die de Standaard Beroepenclassificatie 1992 (SBC'92) van het CBS op dit punt biedt. De aandacht gaat daarbij uit naar het beroepsniveau, het beroepsterrein, de vereiste vaardigheden, de aard van de werkzaamheden en twee aspecten van de kwaliteit van het werk: de fysieke belasting en de kans op buitenwerk.

Hoofdstuk 3 beschrijft de wijze waarop de beroepsgroepen uit de SBC'92 vanuit de gekozen invalshoeken worden getypeerd. De systematiek van deze nieuwe beroepenindeling biedt voor bepaalde dimensies interessante aanknopingspunten. In dit hoofdstuk zal ook telkens een overzicht worden gegeven van de resulterende typeringen van een aantal beroepsgroepen. In hoofdstuk 4 zullen de typeringen van de beroepsgroepen worden getransformeerd naar het beroependomein van de verschillende opleidingstypen. In dit rapport zal bij wijze van voorstudie alleen een beeld worden geschetst van de mogelijke aanvullende informatie die gegeven kan worden over de actuele situatie op de arbeidsmarkt. Daarbij zal ook telkens een overzicht worden gegeven van de resulterende typeringen van een aantal opleidingstypen. De Grip, Borghans en Smits (1997) geven een beeld van de bruikbaarheid van de gevolgde methodiek voor het nader karakteriseren van de verschuivingen in het beroependomein van de diverse opleidingstypen, die op basis van de prognoses verwacht kunnen worden.

In aanvulling op de beschrijving van de verschillende aspecten van de aard van het werk per opleidingstype, kan ook waardevolle informatie worden verstrekt door de geanalyseerde kenmerken van het beroependomein aan elkaar te relateren. Daarbij kan met name gedacht worden aan het combineren van de informatie van enerzijds het beroepsniveau en beroepsterrein en anderzijds de informatie over de te verrichten werksoorten, de vereiste vaardigheden en de kwaliteit van het werk. In

1. Voor Nederland kon hierbij met name gewezen worden op het werk van Benders e.a. (1986) en van het LDC en het CBS op dit gebied. 
hoofstuk 5 wordt bij wijze van voorbeeld ingegaan op de relatie tussen de vereiste vaardigheden en het beroepsterrein waarop hoger opgeleiden werkzaam zijn, verbijzonderd naar het vakspecifieke segment, het gedeelde segment en het uitwijksegment. Voor lager opgeleiden wordt de relatie tussen de fysieke belasting en het beroepsterrein geanalyseerd. In hoofdstuk 6 wordt tot slot geïnventariseerd op welke wijze de informatie over het beroependomein ingepast kan worden in het Informatiesysteem Onderwijs-Arbeidsmarkt. 


\section{Uitgangspunten}

\subsection{Inleiding}

In dit hoofdstuk zal geïnventariseerd worden vanuit welke invalshoeken het beroependomein van opleidingstypen getypeerd kan worden en op welke wijze deze typeringen kunnen worden vastgesteld. Allereerst zal in paragraaf 2.2 worden ingegaan op het onderscheid tussen arbeidsmarktpositie van de afgestudeerden en inhoud van het werk. De arbeidsmarktpositie is een begrip dat mogelijk meer met de opleidingsachtergrond is verbonden, dan met een bepaalde beroepsgroep. Daarentegen is de inhoud van het werk meer gerelateerd aan het beroep dat men uitoefent. Daardoor is de arbeidsmarkt vaak minder transparant met betrekking tot de inhoud van het werk dat de afgestudeerden van een bepaald opleidingstype uitoefenen. Door hier nadere informatie over te geven, wordt een belangrijke aanvulling gegeven op de informatie over de arbeidsmarktpositie van de onderscheiden opleidingstypen. In paragraaf 2.3 wordt de typering van beroepen opgesplitst in twee hoofddimensies. Aan de ene kant kunnen de benodigde vaardigheden als uitgangspunt voor een nadere typering van het beroependomein van opleidingen worden genomen, terwijl aan de andere kant ook de aard van de werkzaamheden centraal gesteld kan worden. Afgeleid van deze twee hoofddimensies zullen in dit rapport vijf invalshoeken worden geanalyseerd. In paragraaf 2.4 wordt vervolgens besproken op welke wijze de kenmerken van een baan kunnen worden vastgesteld.

\subsection{Arbeidsmarktpositie versus inhoud van het werk}

Schaarsteverhoudingen tussen vraag en aanbod op de arbeidsmarkt bepalen primair de mogelijkheden om (bepaald) werk te bemachtigen en de beloningsvoet, maar ook andere aspecten van de arbeidsrelatie, zoals de vraag of men een tijdelijk contract danwel een vaste baan krijgt aangeboden en bijvoorbeeld de mogelijkheden om dit werk in deeltijd te verrichten.

Verschuivende schaarsteverhoudingen kunnen daardoor snel leiden tot veranderingen in de voorwaarden waaronder het werk wordt verricht. Deze arbeidsmarktvoorwaarden die de resultante zijn van marktwerking zijn doorgaans geen intrinsieke eigenschap van een bepaalde functie op zichzelf. Ze kunnen beter gekarakteriseerd worden als kenmerken van de arbeidsmarktpositie van de afgestudeerden van een bepaald opleidingstype. In het informatiesysteem Onderwijs-Arbeidsmarkt wordt aangegeven hoe deze arbeidsmarktpositie zich naar verwachting zal ontwikkelen op de middellange termijn. Uitgaande dat de voor een goed functionerend marktmechanisme vereiste substitutieprocessen mogelijk zijn, is de arbeidsmarktpositie verbonden met een opleidingstype en niet primair met een beroep. Ook vanwege het deels contingente karakter van deze kenmerken kunnen 
ze niet gezien worden als typerend voor een bepaald beroep. leder beroep heeft echter ook eigenschappen die min of meer onlosmakelijk gerelateerd zijn aan de aard van het werk. In dit rapport wordt met name deze inhoud van het werk getypeerd. Vanwege het doorgaans ontbreken van een duidelijke één-op-één relatie tussen een bepaalde opleiding en een bepaald beroep, kan het relateren van de informatie over de inhoud van het beroependomein waarin de afgestudeerden werkzaam zijn, aan het desbetreffende opleidingstype, een waardevolle aanvulling geven op de informatie over de arbeidsmarktpositie c.q. -perspectieven, zoals die thans vanuit het informatiesysteem onderwijs-arbeidsmarkt in beeld wordt gebracht. Zoals later zal blijken is het onderscheid tussen arbeidsmarktpositie en inhoud van werk echter slechts gradueel. Ook de wijze waarop bepaald werk wordt ingericht zal immers afhangen van de beschikbaarheid aan mensen om het uit te voeren. Op de langere termijn zal dus ook de aard van het werk beïnvloed worden door vraagaanbod-verhoudingen.

\subsection{Enkele relevante dimensies}

De eigenschappen die iemand heeft bepalen de wijze waarop hij of zij op de arbeidsmarkt functioneert. Hierdoor zijn sommige persoonskenmerken waardevoller dan andere. Ze leiden tot een hogere productiviteit en daardoor tot een hogere beloning voor de betrokkene. Deze waardevolle kenmerken functioneren dus als een persoonlijk bezit dat men op de arbeidsmarkt ten gelde kan maken. Vandaar dat dit in de economische literatuur wordt aangeduid als menselijk kapitaal. Persoonskenmerken die van belang zijn voor het functioneren op de arbeidsmarkt zijn de menselijke tegenhanger van fysiek kapitaal, dat ook zijn waarde ontleent aan het gebruik dat ervan wordt gemaakt.

Menselijk kapitaal kan verworven worden door ervaring, training of onderwijs. De human-capital-theory benadrukt daarom dat het volgen van onderwijs gezien kan worden als een investering in menselijk kapitaal (Becker, 1964, Schultz, 1961). Ook zonder het menselijk kapitaal te vergroten kan het onderwijs echter een bijdrage leveren aan de arbeidsmarktmogelijkheden van een individu. Onderwijs kan immers ook een signaalfunctie vervullen naar toekomstige werkgevers. Als voor het succesvol volgen van onderwijs bepaalde eigenschappen vereist zijn die ook op de arbeidsmarkt waardevol zijn, kan een gevolgde opleiding het bewijs zijn dat iemand over de desbetreffende eigenschappen beschikt (Spence, 1974).

Voortbouwend op de human-capital-theory gaat de matching theory (Tinbergen, 1956, Hartog, 1985) er van uit dat de productiviteit van arbeidskrachten niet alleen afhangt van hun menselijk kapitaal, maar ook van de wijze waarop dit kapitaal wordt ingezet. Gegeven de arbeidsmarktsituatie zal een bepaalde combinatie van persoonlijke kenmerken en functiekenmerken optimaal zijn. In de praktijk zullen mensen echter ook in functies werkzaam zijn waarbij hun productiviteit niet 
maximaal is. Vanuit de matching-theory is het daarom interessant om beroepen niet alleen te beschouwen vanuit de benodigde persoonskenmerken, waaronder de gevolgde opleiding, maar ook vanuit de feitelijke werkzaamheden die in de functie zullen worden vervuld.

Bij het typeren van het beroepen zullen in dit rapport daarom deze twee dimensies benodigde kwaliteiten en feitelijke werkzaamheden - als uitgangspunt worden genomen. Bij het aangeven van de benodigde kwaliteiten kunnen beroepen getypeerd worden naar het onderwijstype dat voor de functie is vereist. Gezien de opbouw van het onderwijssysteem ligt hierbij een opsplitsing naar het vereiste opleidingsniveau en de vereiste opleidingsrichting voor de hand. In aanvulling daarop kan het menselijk kapitaal dat benodigd is voor een functie getypeerd worden in termen van de vereiste eigenschappen en vaardigheden. Een voordeel van deze laatste typering is dat op deze wijze aan het licht komt welke aspecten van een opleiding cruciaal zijn voor het functioneren in een bepaald beroep. Er wordt als het ware gekeken naar de factoren die schuil gaan achter de vraag naar een bepaald opleidingstype. Voor het opstellen en aanpassen van het curriculum is dergelijke informatie uiteraard cruciaal. Bovendien kunnen op deze wijze ook eigenschappen waarbij het onderwijs een ondergeschikte rol speelt in de analyse worden opgenomen. Dit is vaak van belang voor lagere functies waarbij de vereiste onderwijskwalificaties nogal eens slechts een marginale of indirecte rol spelen, terwijl bijvoorbeeld ook bij het herplaatsingsbeleid van voormalig arbeidsongeschikten informatie over de fysieke of psychische vereisten voor bepaalde functies vaak crucialer is dan de specifieke onderwijsachtergrond.

Ook als de feitelijke werkzaamheden worden geanalyseerd is het zinvol een tweedeling te maken. Ten eerste kunnen beroepen immers getypeerd worden op basis van de activiteiten waarin primair een beroep wordt gedaan op deze benodigde eigenschappen. Hierbij kan gedacht worden aan rekenen, schrijven, leiding geven, enz. Daarnaast worden de feitelijke werkzaamheden ook gekenmerkt door vanuit de menselijk-kapitaal-gedachte meer bijkomstige zaken. Hierbij kan gedacht worden aan de fysieke belasting, de plaats van de werkzaamheden (binnen- of buitenwerk), enz. In dit verband wordt ook wel gesproken van de kwaliteit van het werk. De twee genoemde aspecten van de kwaliteit van werk zullen in dit rapport woden geanalyseerd. Er zijn echter uiteraard diverse andere relevante aspecten. Hierover is vooralsnog echter geen beroepsinformatie beschikbaar.

\subsection{Methodes voor het typeren van beroepen}

Om te komen tot een typering van beroepen vanuit verschillende invalshoeken dient informatie vergaard te worden over de inhoud van het werk. In het algemeen zijn er een drietal methodes waarop dergelijke typeringen tot stand kunnen komen. Dit zijn 
de objectieve, de subjectieve en de empirische methode (zie ook Verdugo en Verdugo, 1989).

Bij de objectieve methode beoordeelt een beroependeskundige op basis van een aantal observaties van individuele functies welke typeringen aan bepaalde beroepen gegeven moeten worden. Bij de subjectieve methode wordt dit oordeel overgelaten aan degene die het beroep uitoefent. In principe zou ook de werkgever om dit oordeel gevraagd kunnen worden. Bij typeringen die betrekking hebben op het genodigde menselijk kapitaal, kan ook gekeken worden naar de feitelijke situatie. Dit is de empirische methode. Deze aanpak is echter niet bruikbaar voor het typeren van de inhoud van het werk, omdat hierbij geen verband gelegd wordt tussen een beroep en kenmerken van degenen die dit beroep uitoefenen.

$\mathrm{Bij}$ de keuze voor een van de drie typeringsmethoden moet een afweging van de voor- en nadelen worden gemaakt. Hierbij spelen de beschikbaarheid van de gegevens en de betrouwbaarheid van de methode een rol. Onbetrouwbaarheid kan voortkomen uit onjuistheden in het oordeel en veroudering van het oordeel.

Bij de objectieve methode is vooral de veroudering dikwijls een groot probleem. Experts beoordelen op een bepaald moment beroepen, waarbij vervolgens veelal gedurende lange tijd dezelfde typeringen worden gehanteerd ${ }^{2}$. Actualisering van de typering vraagt een volledig nieuwe beoordeling, die, vanwege de hoge kosten die daarmee gepaard gaan, in de praktijk slechts sporadisch plaatsvindt. Bovendien is het twijfelachtig of experts graduele veranderingen in de inhoud van een beroep op zullen merken. Daarnaast vindt oordeelsvorming altijd plaats op een beperkt aantal functies die als voorbeeld dienen voor een gehele beroepsgroep.

Bij de subjectieve methode worden deze aspecten voor elke functie door de betrokkenen zelf beoordeeld waardoor graduele veranderingen beter gesignaleerd kunnen worden. Gebrek aan expertise kan echter betekenen dat een werknemer zelf een vertekend beeld van zijn positie heeft. Doordat men alleen de eigen situatie kent is het moeilijker deze positie in een vergelijkend perspectief te plaatsen, waardoor mogelijk fouten in de beoordeling ontstaan. Zeker als het gaat om systematische vertekeningen kan dit de kwaliteit van de typering verslechteren.

Bij de empirische methode, die zoals gezegd alleen kan worden gevolgd bij het typeren van het vereiste opleidingsniveau en de vereiste opleidingsrichting, wordt op basis van feitelijke opleidingsachtergronden van degenen die in een bepaald beroep werkzaam zijn geconcludeerd welke opleiding kennelijk vereist is. Een groot voordeel van deze methode is dat er een continue aanpassing van de typering

2. Een bekend voorbeeld hiervan is de typering van het beroepsniveau van de CBSBeroepenclassificatie die enkele decennia is gehanteerd (zie bijvoorbeeld Huygen, 1989). 
mogelijk is. Daarbij speelt echter de vraag of het feit dat een groot deel van de werkenden een bepaalde opleidingsachtergrond heeft ook betekent dat deze opleiding vereist is ${ }^{3}$. De beoordeling van deze kwestie is afhankelijk van de wijze waarop een functievereiste wordt geïnterpreteerd. Ten eerste kan er aan een bepaalde opleidingsvereiste een absolute betekenis aan een functievereiste worden gegeven. In dat geval bestaan er voor elke functie eenduidig vastgelegde eisen, die geheel los staan van de marktverhoudingen. Er kan echter ook een relatieve betekenis aan de opleidingsvereisten voor een bepaald beroep worden gegeven. In dat geval wordt aangenomen dat een bepaald beroep uitgeoefend kan worden met verschillende soorten menselijk kapitaal, maar dat de productiviteit kan varieren met op opleidingsachtergrond van de werkende De vraag welke personen dan het beste ingezet kunnen worden voor een bepaalde taak hangt dan af van de schaarsteverhoudingen. Het voordeel van een hoge productiviteit kan immers wegvallen tegen hoge arbeidskosten. De vraag welke kenmerken vereist zijn voor een functie wordt daarmee een resultaat van marktkrachten. Een gevolg hiervan is dat, zoals reeds werd opgemerkt, ook de aard van het werk gedeeltelijk bepaald wordt door schaarsteverhoudingen. Er van uitgaande dat een groot deel van de werkenden goed gealloceerd is, impliceert dit dat de empirische methode bij uitstek geschikt is om de 'optimale' opleidingsvereisten te typeren. Met name bij zeer grote veranderingen kan deze aanname uiteraard zijn geldigheid verliezen.

In dit rapport wordt deze relatieve interpretatie van functievereisten als uitgangspunt genomen. Omdat daarnaast grote waarde wordt gehecht aan een maatstaf die actueel blijft, en daarmee de ontwikkelingen op de arbeidsmarkt volgt gaat in principe de eerste voorkeur uit naar de empirische methode. Vanwege de actualiteitswaarde gaat de tweede voorkeur uit naar de subjectieve methode terwijl de objectieve methode op de derde plaats komt. De beschikbaarheid van data en de kwaliteit van deze data kunnen de definitieve keuze van de methode om een bepaald aspect van een beroep te typeren echter verder beïnvloeden.

De beoordeling van de kenmerken van een beroep behelst altijd een zekere mate van aggregatie. Zowel de subjectieve en objectieve oordelen, als de empirsche verdeling zullen immers per beroepsgroep een divers beeld te zien geven. Voor een deel komt deze diversiteit voort uit meetonzekerheid en graduele verschillen tussen functies binnen een beroepsgroep. Daarnaast kan er echter ook sprake zijn van heterogeniteit van een beroepsgroep, waardoor uiteenlopende functies met verschillende kenmerken ten onrechte op een hoop gegooid worden. Daar de in de SBC'92 onderscheiden beroepsgroepen in belangrijke mate gebaseerd zijn op de vereiste opleidingsachtergronden, mag verwacht worden dat de beroepsgroepen op

3. Duidelijk is dat in ieder geval het omgekeerde wel moet gelden. Als een groot deel van de werkenden een bepaalde opleidingsachtergrond niet heeft, kan deze ook niet vereist zijn. 
dit punt relatief homogeen zijn. Voor de andere invalshoeken waaruit de beroepsgroepen hier getypeerd zullen worden is dit mogelijk niet het geval.

De aard van de heterogeniteit kan van invloed zijn op de betekenis die eraan moet worden toegekend. Stel dat een beroepsgroep gekenmerkt wordt door $50 \%$ binnenen $50 \%$ buitenwerk. Dit kan in de eerste plaats betekenen dat werkenden in dit beroep de helft van hun tijd binnen en de helft van hun tijd buiten werken. Ook zou dit kunnen betekenen dat voor de helft van de betrokkenden geldt dat men doorgaans binnen werkt, terwijl voor de andere helft geldt dat men doorgaans buiten werkt. In dit tweede geval is het belangrijk om te weten of op dit punt in principe nog een keuzevrijheid bestaat, of dat de betrokkene zonder daarop invloed te hebben met beide aspecten geconfronteerd wordt. Verder bestaat de mogelijkheid dat binnen een bepaalde beroepsgroep mensen met een bepaalde opleidingsachtergrond slechts één bepaald beroep uitoefenen. Juist voor dit beroep zou ondanks de heterogeniteit van de beroepsgroep, altijd dezelfde eigenschap van toepassing kunnen zijn.

De gehanteerde typeringen zullen daarom sterk afhankelijk zijn van de kwaliteit van de gebruikte beroepenclassificatie. Als beroepen met een uiteenlopend karakter ten onrechte in een beroepsgroep zijn opgenomen leidt dit mogelijk tot problemen. Als daarentegen in een beroepsgroep de beroepen van vergelijkbare aard zijn samengenomen, zou in het geval van afbakeningsproblemen - het ene beroep wordt net wel en het andere net niet als fysiek zwaar gekenmerkt - het groepsgemiddelde een treffende indicatie van dit grenskarakter kunnen geven. 


\section{Typeringen van beroepsgroepen}

\subsection{Inleiding}

In dit hoofdstuk zal vanuit de in hoofdstuk 2 genoemde invalshoeken een typering worden gegeven van de verschillende beroepsgroepen, zoals die in de nieuwe beroepenclassificatie van het SBC'92 worden onderscheiden. Daarbij zal bij het vaststellen van het beroepsniveau en -terrein gebruik gemaakt worden van de empirische methode, waarbij direct gekeken worden naar de opleidingsachtergrond van de werkenden in een bepaalde beroepsgroep. Bij het typeren van de te verrichten werksoorten, de vereiste vaardigheden en de kans op buitenwerk zal daarentegen gebruik gemaakt worden van de objectieve methode. In deze gevallen gaat het telkens om het transformeren van de kenmerken van de in totaal 1211 beroepen naar het hogere aggregatieniveau van de beroepsgroepen, waarvan er hier 126 worden onderscheiden. De informatie die besloten ligt in de nieuwe beroepenclassificatie wordt als bron voor de beroepenkundige gegevens gehanteerd. Bij de aggregatie deze informatie van beroepen naar beroepsgroepen wordt gewogen op grond van de verdeling van werkzame personen over de beroepen in 1994. Daarentegen wordt bij typeringen volgens de empirische methode van het beroepsniveau en -terrein direct een typering gegeven op basis van de waargenomen opleidingsachtergronden van de werkenden in de desbetreffende beroepsgroep.

In de SBC'92 zelf worden 121 beroepsgroepen onderscheiden. Deze indeling heeft echter als nadeel dat op het laagste beroepsniveau - de elementaire beroepen alle 34 onderliggende beroepen worden geaggregeerd tot één beroepsgroep, waarin in 1995 in totaal 360.000 mensen werkzaam waren. Deze samenvoeging is weliswaar consistent ten aanzien van de uitgangspunten van de beroepenclassificatie, maar heeft als nadeel dat qua karakter duidelijk uiteenlopende beroepen tot een niet-differentieerbare groep worden samengevoegd (zie ook De Grip, 1995). Cruciaal hierbij is dat volgens de systematiek van het CBS beroepen met dezelfde opleidingsvereisten in een beroepsgroep worden samengenomen. Hierbij wordt impliciet aangenomen dat de arbeidskrachten voor dergelijke beroepen substitueerbaar zijn. Zoals reeds eerder is opgemerkt is voor de laagste functies niet in de eerste plaats de opleidingsachtergrond cruciaal, maar spelen vormen van menselijk kapitaal die niet via het onderwijs worden verworven veelal de doorslag bij de geschiktheid voor een functie. In samenspraak met het CBS is daarom besloten de elementaire beroepen op te splitsen in zes beroepsgroepen, te weten:

- algemene elementaire beroepen;

- elementaire agrarische beroepen;

- elementaire technische beroepen;

- elementaire transportberoepen;

- elementaire administratieve, commerciële beroepen; 
- elementaire verzorgende beroepen.

\subsection{Typering beroepsniveau}

Als eerste invalshoek voor de typering van beroepsgroepen wordt in deze paragraaf ingegaan op het beroepsniveau. Zoals in hoofdstuk 2 reeds is besproken, kan het niveau van een functie worden vastgesteld door een verband te leggen tussen de functie en de benodigde vaardigheden uit het onderwijssysteem. Voor een typering van het beroepsniveau kan gebruik worden gemaakt van zowel de objectieve, de subjectieve en de empirische methode (zie ook Groeneveld, 1996, Hartog en Jonker, 1997). Doordat de nieuwe beroepenclassificatie van het CBS beroepen indeelt in diverse niveaus op grond van een beroepenkundig oordeel is hier feitelijk sprake van een objectieve indeling. Daarnaast wordt in een aantal enquêtes onder werkenden de vraag voorgelegd welk opleidingsniveau vereist is voor de huidige functie. Een dergelijke vraag is te vinden in ondermeer de schoolverlatersenquêtes, het OSA-aanbodpanel en het Sociaal Economisch Panel van het CBS. Doordat deze bronnen danwel niet de gehele arbeidsmarkt beslaan, danwel te klein van omvang zijn voor betrouwbare informatie op het niveau van beroepsklassen, zijn er momenteel nog onvoldoende gegevens om de subjectieve methode voor het typeren van het beroepsniveau toe te passen. In ROA (1995b) wordt de subjectieve methode wel reeds toegepast om de positie van schoolverlaters op de arbeidsmarkt te karakteriseren. Doordat de Enquête Beroepsbevolking informatie verschaft over de opleidingsachtergrond van de werkzame beroepsbevolking kan ook de empirische methode worden toegepast voor het vaststellen van het beroepsniveau. Op grond van de criteria in hoofdstuk 2 zal deze empirische invalshoek hier worden gehanteerd.

In de praktijk zijn uiteraard in een groot aantal gevallen mensen met verschillende opleidingsniveaus te vinden in eenzelfde beroepsgroep. Deze heterogeniteit kan deels verklaard worden doordat een deel van de personen een baan heeft die qua niveau niet aansluit bij de opleiding. Er kan hierbij zowel sprake zijn van onder- als van overscholing. Verder is het uiteraard mogelijk dat meerdere opleidingsniveaus goed aansluiten bij een bepaald beroep. Als de productiviteit in een bepaalde baan toeneemt met het genoten opleidingsniveau, dan zal het vereiste niveau afhankelijk zijn van de verhouding tussen loonkosten en productiviteit. Doorgaans wordt aangenomen dat de productiviteit aanvankelijk sterk toeneemt met het niveau, maar vanaf een bepaalde hoogte niveauverhoging niet veel invloed meer heeft op de productiviteit. Het optimale opleidingsniveau ligt dan doorgaans bij deze knik. Als het verband tussen opleidingsniveau en productiviteit echter geleidelijker verloopt, is het goed denkbaar dat er meerdere opleidingsniveaus zijn die goed aansluiten op een bepaalde functie. Hoger opgeleiden zijn dan welliswaar duurder, maar compenseren dit verschil door hun hogere productiviteit. 
De empirische methode voor het vaststellen van het niveau van een beroep kan deze diversiteit aan het licht brengen. Om de methode hanteerbaar te maken dienen er echter criteria gesteld te worden om de niveaus af te bakenen. Hier is in navolging van De Grip, Borghans en Smits (1997) gekozen voor het volgende criterium. Gekeken wordt naar de percentages werkenden met een bepaalde opleidingsachtergrond in het betreffende beroep.

(1) Als meer dan $50 \%$ van de werkenden in een beroep een bepaald opleidingsniveau heeft en elk van de andere niveaus voor minder dan $40 \%$ is vertegenwoordigd, dan wordt het desbetreffende beroep aan dit meerderheidsniveau toegewezen.

(2) Als bij een beroep $50 \%$ van de werkenden een bepaald opleidingsniveau heeft, maar daarnaast meer dan $40 \%$ van de werkenden een bepaald onder opleidingsniveau heeft, dan krijgt het beroep een dubbele typering van beide niveaus. In de praktijk gaat het altijd om twee opeenvolgende niveaus.

Als er geen niveau is dat een meerderheidsaandeel heeft dan geldt:

(3) Als twee opeenvolgende niveaus meer dan $50 \%$ van de werkgelegenheid vertegenwoordigen en er geen andere combinatie van opeenvolgende niveaus is waarvoor dit geldt dan krijgt het beroep deze dubbele typering.

(4) Als twee combinaties van opeenvolgende niveaus beide een aandeel van minstens $50 \%$ hebben dan wordt een drievoudige typering van deze drie niveaus gegeven.

(5) Als aan geen van deze criteria is voldaan wordt geen niveautypering gegeven.

Uiteraard betekent iedere afbakening dat er grensgevallen ontstaan die net wel of net niet in een bepaalde groep terecht komen. Dergelijke grensgevallen zijn echter niet te vermijden. Tabel 3.1 laat de resultaten van de gehanteerde indeling zien voor een 22-tal geselecteerde beroepsgroepen. Doordat de beroepsnamen van het CBS gebaseerd zijn op de door het CBS gehanteerde beroepenkundige niveautypering kan in deze tabel een vergelijking tussen beide aanpakken worden gemaakt.

Opvallend is dat de elementaire beroepen en de lagere beroepen vrijwel allemaal getypeerd zijn met meerdere niveaus, waarvan de hoogste het objectief vastgestelde niveau ontstijgt. De enige uitzondering zijn de lagere bouwkundige beroepen die ook empirisch de typering VBO hebben gekregen. Deze brede typering van deze beroepsgroepen weerspiegelt de ook reeds in ROA (1995a) geconstateerde tendens dat voor vrijwel alle beroepen die scholing vereisen tegenwoordig minimaal MBO/leerlingwezen vereist is. Dat betekent dat de lagere 
beroepen deels een MBO-predicaat krijgen en VBO'ers voor een groot deel terecht komen in de vanoudsher als ongeschoold getypeerde beroepen.

Voor de middelbare, hogere en wetenschappelijke beroepen blijken de empirische en beroepenkundige typeringen minder vaak uiteen te lopen. Van de in de tabel opgenomen beroepsgroepen zijn de hogere commerciële beroepen en de managers op wetenschappelijk niveau de enige uitzonderingen. Ook in ROA (1995a) werd juist bij de economisch/administratieve beroepen een sterke overlap in niveaus gecontateerd. Het ligt voor de hand dat juist bij deze beroepen het verband tussen beloning en productiviteit gradueel is, waardoor het mogelijk is dat mensen met een verschillend opleidingsniveau allen een productiviteit hebben die aansluit bij hun beloningsniveau. Bij beroepen in het onderwijs en de medische sector zal de optimale productiviteit veel sterker aan één bepaald opleidingsniveau gekoppeld zijn.

Tabel 3.1

Typering van het niveau van een aantal beroepsgroepen

\begin{tabular}{|c|c|}
\hline Beroepsgroep & Niveau-typering \\
\hline $\begin{array}{l}\text { Elementaire technische beroepen } \\
\text { Elementaire verzorgende beroepen } \\
\text { Lagere algemeen agrarische beroepen } \\
\text { Lagere bouwkundige beroepen } \\
\text { Lagere algemene transportberoepen } \\
\text { Lagere verkoopberoepen } \\
\text { Middelbare werktuigbouwkundige beroepen e.d. } \\
\text { Middelbare procestechnische beroepen } \\
\text { Middelbare algemene (para)medische beroepen } \\
\text { Middelbare commerciële beroepen } \\
\text { Middelbare algemeen verzorgende beroepen } \\
\text { Docenten basisonderwijs, algemeen vormende vakken } \\
\text { Hogere bouwkundige, technische beveiligingsberoepen } \\
\text { Hogere algemene, verzorgende (para)medische beroepen } \\
\text { Hogere administratieve beroepen (automatisering ed.) } \\
\text { Hogere commerciële beroepen ed. } \\
\text { Hogere sociaal-maatschappelijke beroepen } \\
\text { Docenten taalkundige, culturele vakken (1e gr. en wO) } \\
\text { Wetenschappelijke wiskundige, natuurwetenschappelijke beroepen } \\
\text { Wetenschappelijke (para)medische beroepen (excl. technisch) ed. } \\
\text { Wetenschappelijke juridische, bestuurlijke beroepen } \\
\text { Managers (wetenschappelijk werk- en denkniveau) }\end{array}$ & $\begin{array}{l}\text { BO/NBO/MBO } \\
\text { BO/NBO } \\
\text { VBO/MBO } \\
\text { VBO } \\
\text { BO/NBO/MBO } \\
\text { VBO/MBO } \\
\text { MBO } \\
\text { MBO } \\
\text { MBO } \\
\text { MBO } \\
\text { MBO } \\
\text { HBO } \\
\text { HBO } \\
\text { HBO } \\
\text { HBO } \\
\text { MBO/HBO } \\
\text { HBO } \\
\text { WO } \\
\text { WO } \\
\text { WO } \\
\text { WO } \\
\text { HBO/WO }\end{array}$ \\
\hline
\end{tabular}

\subsection{Typering beroepsterrein}

Een tweede invalshoek om aan te geven welk type onderwijs vereist is voor een bepaald beroep betreft het beroepsterrein. Hierbij staat niet het niveau, maar de richting van het onderwijs die vereist is voor het desbetreffende beroep centraal. Ook hier staan in principe de objectieve, de subjectieve en de empirische methode ter beschikking. Opgemerkt dient echter te worden dat de bestaande enquêtes niet 
zijn toegerust voor de subjectieve aanpak. Er wordt wel gevraagd of het beroep waarin men werkzaam is de gevolgde opleiding vereist, maar bij een negatief antwoord wordt niet de vraag gesteld welke opleiding wel werd vereist. Net als in de vorige paragraaf wordt ook hier de analyse gebaseerd op de empirische methode, terwijl in de SBC'92 impliciet de beroepenkundige aanpak zit verwerkt. Deze kan dus wederom ter vergelijking dienen.

Ook voor de indeling naar beroepsterrein zijn criteria vastgesteld conform De Grip, Borghans en Smits (1997):

(1) Als meer dan $50 \%$ van de werkenden in een beroepsgroep een opleiding in een bepaalde richting heeft en alle andere richingen een percentage werkenden hebben dat minstens $10 \%$ lager is, dan wordt het beroep aan deze meerderheidsrichting toegewezen.

(2) Als naast een opleidingsrichting die door meer dan $50 \%$ van de werkenden is gevolgd, echter ook een andere richting een vertegenwoordiging heeft minder dan $10 \%$ lager is, dan krijgt het beroep een dubbele typering van beide richtingen, die zal worden aangeduid als het 'gedeelde segment'.

Als er geen richting is dat een meerderheidsaandeel heeft dan geldt:

(3) Als een richting meer dan $40 \%$ van de werkgelegenheid vertegenwoordigt en deze richting tezamen met een andere richting meer dan $50 \%$ van de werkgelegenheid vertegenwoordigen en er geen andere combinatie van richtingen voorkomt waarvoor dit ook geldt, dan krijgt het beroep deze dubbele typering, die zal worden aangeduid als het 'gedeelde segment'.

(4) Als een richting meer dan $40 \%$ van de werkgelegenheid vertegenwoordigt en met twee combinaties van richtingen beide een aandeel van minstens $50 \%$ heeft, dan wordt de typering van de grootste opleiding gegeven gecombineerd met een andere als deze als enige een aandeel heeft van meer dan $20 \%$. Zijn alle andere aandelen lager dan $20 \%$ dan wordt de combinatietypering van de grootste opleiding met 'algemeen' gegeven.

(5) Als aan geen van deze criteria is voldaan wordt de typering 'algemeen' gegeven.

De analyses zijn gebaseerd op de volgende acht opleidingsrichtingen:

BOIAVO

agrarisch

technisch

(para)medisch en laboratorium

economisch-administratief 
sociaal-cultureel en letteren

onderwijs

verzorgend

Tabel 3.2

Typering van het terrein van een aantal beroepsgroepen

\begin{tabular}{|c|c|}
\hline Beroepsgroep & Terreintypering \\
\hline $\begin{array}{l}\text { Elementaire technische beroepen } \\
\text { Elementaire verzorgende beroepen } \\
\text { Lagere algemeen agrarische beroepen } \\
\text { Lagere bouwkundige beroepen } \\
\text { Lagere algemene transportberoepen } \\
\text { Lagere verkoopberoepen } \\
\text { Middelbare werktuigbouwkundige beroepen e.d. } \\
\text { Middelbare procestechnische beroepen } \\
\text { Middelbare algemene (para)medische beroepen } \\
\text { Middelbare commerciële beroepen } \\
\text { Middelbare algemeen verzorgende beroepen } \\
\text { Docenten basisonderwijs, algemeen } \\
\text { vormende vakken } \\
\text { Hogere bouwkundige, technische } \\
\text { beveiligingsberoepen } \\
\text { Hogere algemene, verzorgende } \\
\text { (para)medische beroepen } \\
\text { Hogere administratieve beroepen } \\
\text { (automatisering ed.) } \\
\text { Hogere commerciële beroepen ed. } \\
\text { Hogere sociaal-maatschappelijke beroepen } \\
\text { Docenten taalkundige, culturele } \\
\text { vakken (1e gr. en WO) } \\
\text { Wetenschappelijke wiskundige, natuurweten- } \\
\text { schappelijke beroepen } \\
\text { Wetenschappelijke (para)medische beroepen } \\
\text { (excl. technisch) ed. } \\
\text { Wetenschappelijke juridische, } \\
\text { bestuurlijke beroepen } \\
\text { Managers (wetenschappelijk werk- en denkniveau) }\end{array}$ & $\begin{array}{l}\text { Technisch/BO/AVO } \\
\text { BO/AVO } \\
\text { Agrarisch/BO/AVO } \\
\text { Technisch } \\
\text { Technisch/BO/AVO } \\
\text { Algemeen } \\
\text { Technisch } \\
\text { Technisch } \\
\text { (Para)medisch en laboratorium } \\
\text { Economisch-administratief/BO/AVO } \\
\text { Verzorgend } \\
\text { Onderwijs } \\
\text { Technisch } \\
\text { (Para)medisch en laboratorium } \\
\text { Technisch/Economisch-administratief } \\
\text { Economisch-administratief } \\
\text { Sociaal-cultureel en letteren } \\
\text { Sociaal-cultureel en letteren } \\
\text { Technisch } \\
\text { (Para)medisch en laboratorium } \\
\text { Economisch-administratief } \\
\text { Technisch/Economisch-administratief }\end{array}$ \\
\hline
\end{tabular}

Ook basisonderwijs en algemeen onderwijs (BO/AVO) vormen hierin een potentieel vakspecifiek terrein. Tabel 3.2 toont de resultaten van deze terreintypering van de 26 geselecteerde beroepsgroepen. Opvallend is dat slecht in een beperkt aantal gevallen een dubbele typering is gegeven. Bij de lagere en elementaire beroepen komt een combinatie met BO/AVO regelmatig voor, terwijl de middelbare commerciële beroepen, de hogere administratieve beroepen en de managers met wetenschappelijk werk- en denkniveau de economisch/administratieve richting combineren met respectievelijk BO/AVO en tweemaal een technisch werkterrein. Voor de hogere administratieve beroepen, die hoofdzakelijk uit automatiseringsberoepen bestaan ligt de combinatie tussen economischadministratief en techniek voor de hand, omdat beide opleidingsrichtingen elk vanuit hun eigen invalshoek voor dit vak opleiden. Managers op wetenschappelijk niveau blijken doorgaans danwel een technische, danwel een economisch-administratieve 
opleidingsachtergrond te hebben. Een belangrijk criterium bij de SBC'92 om managers op het wetenschappelijk niveau te plaatsen is het aantal personen waaraan leiding wordt gegeven. Omdat grote bedrijven met name veel in de industrie te vinden zijn weerspiegelt deze dubbeltypering het bekende dillema tussen een technicus en een econoom voor de leiding van een fabriek.

Verder is opmerkelijk dat de lagere verkoopberoepen de typering algemeen krijgen. Kennelijk is de opleidingsachtergrond voor dit beroep niet meer cruciaal voor het verwerven van een baan in de verkoop, zodat personen met een uiteenlopende achtergrond hier werkzaam zijn. Ook dit werd reeds eerder gecontateerd in ROA (1995a), waar bleek dat een groot aantal opleidingen op lager en middelbaar niveau een overlap in het beroepsdomein had vanwege werkzaamheden als verkoper. Door het gebruik van de empirische methode kan een dergelijke tendens aan het licht komen. Verder blijkt de empirische methode volledig te sporen met de conclusies van de beroepenkundige analyse van het CBS.

\subsection{Typering vereiste vaardigheden}

De SBC'92 biedt ook de mogelijkheid per beroep aanvullende informatie te genereren over de vereiste 'specifieke vaardigheden'. Daarbij worden in totaal 11 vaardigheden onderscheiden. Tabel 3.3 geeft hiervan een overzicht.

Tabel 3.3

De elf expliciet gemaakte specifieke vaardigheden

1. Kwantitatief
2. Technisch
3. Leidinggevend
4. Organisatie en ordening eigen werk

5. Verbaal

6. Kunstzinnig

7. Service-gerichtheid

8. Persuasief

9. Handvaardigheden

10. Ruimtelijk voorstellingsvermogen

11. Oplettendheid
Werkzaamheden waarbij gerekend moet worden Het werken met machines en gereedschappen Werkzaamheden waarbij sprake is van of beleidvoeren, of leidinggeven, of toezichthouden

Werkzaamheden waarbij het van belang is de eigen arbeid tot een doelmatig functionerend geheel te ordenen, waaronder het overzichtelijk en systematisch opbergen van gereedschappen en materialen

Werkzaamheden waarbij eisen worden gesteld betreffende het mondeling of schriftelijk weergeven van gedachten en gevoelens in woorden

Werkzaamheden waarbij eisen worden gesteld aan de expressieve of esthetische vormgeving Werkzaamheden die gericht zijn op dienstverlening aan personen

Werkzaamheden waarbij mensen in direct contact beïnvloed moeten worden

Werkzaamheden waarbij handmatig of met eenvoudig handgereedschap produkten of delen van produkten worden vervaardigd

Werkzaamheden waarbij het erom gaat zich een voorstelling te maken van ruimtelijkheden en waarbij het schatten van afmetingen en maatverhoudingen een rol speelt

Werkzaamheden waarbij het van belang is attent te zijn op voor het werk van belang zijnde details.

Bron: CBS 
De vereiste vaardigheden zijn afgeleid van de onderscheiden werksoorten. Op basis daarvan is elk beroep getypeerd naar maximaal 7 vereiste vaardigheden (CBS, 1993). In aansluiting op onder andere Bishop (1995) zijn deze 11 vaardigheden samengevoegd tot 5 hoofdcategorieën, aangevuld met de categorie 'geen specifieke vaardigheid vereist'. Tabel 3.4 heeft hiervan een overzicht. Uit deze samenvoeging blijkt dat de vakspecifieke vaardigheden vanuit de door het CBS-onderscheiden specifieke vaardigheden slechts beperkt kunnen worden ingevuld. Met name ten aanzien van de vakspecifieke medische en juridische kennis en vaardigheden lijkt hier sprake te zijn van een lacune in de onderscheiden vaardigheden.

Tabel 3.4

Clustering van specifieke vaardigheiden in zes vereiste vaardigheden

1. Vakspecifieke vaardigheden:

- Kwantitatieve vaardigheden

- Technische vaardigheden

- Handvaardigheden

2. Management vaardigheden:

- Leidinggevend vermogen

3. Communicatieve vaardigheden:

- Verbale vaardigheden

- Service-gerichtheid

- Persuasief vermogen

4. Algemene vaardigheden:

- Vermogen om eigen werk te ordenen en te organiseren

- Ruimtelijk voorstellingsvermogen

- Oplettendheid

5. Kunstzinnige vaardigheden

6. Geen specifieke vaardigheid

In hoeverre de hierboven genoemde vaardigheden van belang zijn voor de verschillende beroepsgroepen, komt naar voren in tabel 3.5. In het algemeen blijken de vakspecifieke vaardigheden vooral van belang bij de elementaire, lagere en middelbare beroepen, terwijl de communicatieve vaardigheden voor de middelbare, hogere en wetenschapelijke beroepen relatief belangrijk zijn. Daarbij moet de kanttekening gemaakt worden, dat het zeer lage belang van vakspecifieke vaardigheden bij de middelbare en hogere algemene (para)medische beroepen waarschijnlijk voor een belangrijk deel het gevolg is van het ontbreken van een vakspecifieke vaardigheid in de CBS-indeling, die betrekking heeft op de (para)medische functies. Opvallend is verder het feit dat voor alle managers op wetenschappelijk werk- en denkniveau zowel vakspecifieke-, management- én communicatieve vaardigheden van belang zijn. 


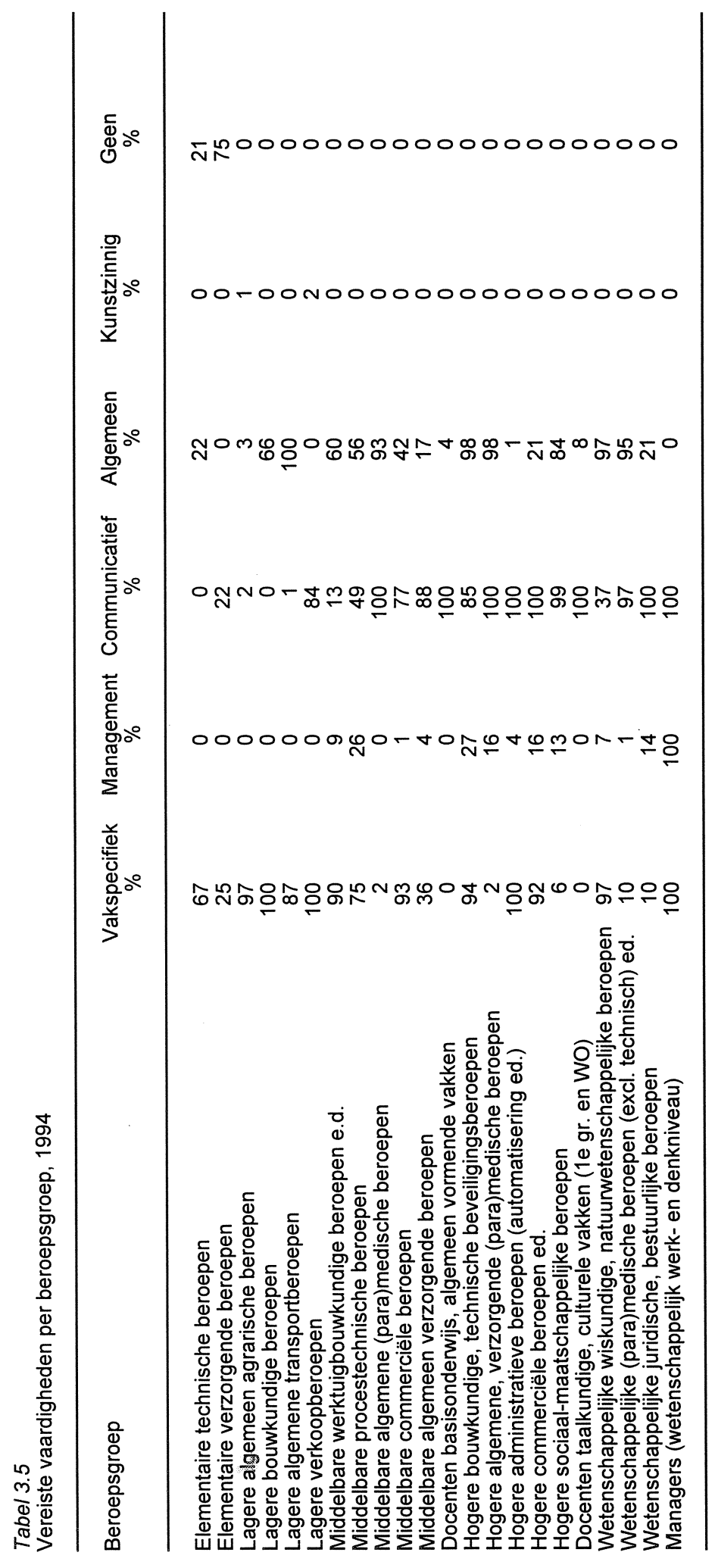




\subsection{Typering aard van de werkzaamheden}

De in de SBC'92 onderscheiden beroepen zijn door het CBS getypeerd op basis van de 'werksoorten' die kenmerkend zijn voor het takenpakket van het desbetreffende beroep. De daarbij gehanteerde lijst van werksoorten is ontleend aan het informatiesysteem van het Centraal Bureau Arbeidsvoorziening (De Winkel, 1990). Het CBS onderscheidt daarbij in totaal 128 werksoorten. Elk beroep wordt op basis van maximaal drie werksoorten getypeerd (CBS, 1993).

Om een beeld te krijgen van de belangrijkste werksoorten in een bepaalde beroepsgroep, zijn de voor de verschillende onderliggende beroepen relevante werksoorten geaggregeerd. Daarbij zijn de aan een bepaald beroep toegekende werksoorten telkens gewogen met het aandeel van het desbetreffende beroep in het totaal aantal werkenden in de beroepsgroep waaronder het beroep resorteert. Op deze wijze kan per beroepsgroep worden aangegeven welk deel van de werkenden een bepaalde activiteit verricht. Deze aanpak veronderstelt aan de ene kant dat alle werkenden in de beroepen, waaraan een bepaalde werksoort is toegekend, de desbetreffende werksoort verrichten. Aan de andere kant wordt verondersteld dat voor geen van de werkenden in de andere beroepen deze werksoort relevant is.

Tabel 3.6 geeft een overzicht van de voor een aantal beroepsgroepen belangrijkste werksoorten. De tabel maakt duidelijk dat er grote verschillen in de mate van homogeniteit naar werksoorten worden aangetroffen. Zo bestaan er beroepsgroepen, waarvan alle beroepsbeoefenaars een bepaalde werksoort verrichten, zoals de docenten basisonderwijs, algemeen vormende vakken en taalkundige, culturele vakken (100\% van hen geeft les). Andere beroepsgroepen kennen één of enkele overheersende werksoorten, zoals de elementaire verzorgende beroepen ( $76 \%$ van hen maakt schoon in huishoudens of kantoren), de lagere verkoopberoepen ( $84 \%$ verkoopt) en de hogere administratieve beroepen (met $83 \%$ beoefenaars die informatica ontwikkelen cq. adviseren). Daarnaast zijn er beroepsgroepen met relatief veel heterogeniteit in de activiteiten die men verricht, bijvoorbeeld de lagere bouwkundige beroepen en de middelbare procestechnische beroepen.

\subsection{Typering kwaliteit van het werk}

\section{Fysieke belasting}

Om een beeld te kunnen geven van de fysieke belasting die de werkzaamheden in een bepaald beroep met zich meebrengen, zijn alle 128 door het CBS onderscheiden werksoorten getypeerd als fysiek belastende of niet fysiek belastende activiteiten. Daarbij is vooral gekeken of er een fysieke inspanning geleverd moet worden; dat wil zeggen dat bijvoorbeeld werkzaamheden waarvoor iemand bijna de hele dag in een bepaalde houding moet zitten, hier niet als fysiek belastend zijn getypeerd. 
Tabel 3.6

Belangrijke werksoorten per beroepsgroep, 1994

Beroepsgroep

-werksoort

Elementaire technische beroepen

- produktiemachines, -apparatuur bedienen

- transporteren, sjouwen

- controleren, testen, sorteren

Elementaire verzorgende beroepen

- schoonmaken huishoudelijk, kantoor

- afrekenen

- serveren

Lagere algemeen agrarische beroepen

- tuinbouwwerk verrichten

- veeteeltwerk verrichten

- landbouwwerk verrichten (excl. veeteelt

Lagere bouwkundige beroepen

- timmeren

- schilderen, verven, spuiten

- metselen, voegen, tegelzetten

Lagere algemene transportberoepen

- bezorgen

- besturen vrachtauto

- mobiele machines, kranen bedienen

Lagere verkoopberoepen

- verkopen (excl. vertegenwoordigen)

- afrekenen

- beeldende kunst beoefenen

Middelbare werktuigbouwkundige beroepen e.d.

- monteren, samenbouwen: machines, apparatuur 36

- onderhouden, repareren: (motor-) voertuigen

- leidinggeven aan uitvoerenden zonder beleid

Middelbare procestechnische beroepen

- produktieprocessen bewaken

- leidinggeven aan uitvoerenden zonder beleid

- verkopen (excl. vertegenwoordigen)

Middelbare algemene (para)medische beroepen

- verplegen

- geneeskundig assisteren: niet technisch

- administreren; teksten

Middelbare commerciële beroepen

- verkopen (excl. vertegenwoordigen)

- verkopen; vertegenwoordigen

- administreren; cijfermatig

Middelbare algemeen verzorgende beroepen

- verzorgen, helpen mensen

- verkopen (excl. vertegenwoordigen)

- verzorgen uiterlijk 
Tabel 3.6 (vervolg)

Belangrijke werksoorten per beroepsgroep, 1994

Beroepsgroep

-werksoort

Docenten basisonderwijs, algemeen vormende vakken

- les geven, doceren

- agogisch, maatschappelijk begeleiden

Hogere bouwkundige, technische beveiligingsberoepen

- ontwerpen, construeren

- werkvoorbereiden, werk coördineren

- leidinggeven aan uitvoerenden zonder beleid

Hogere algemene, verzorgende (para)medische beroepen

- verplegen

- therapeutisch begeleiden (fysiek)

- leidinggeven aan uitvoerenden zonder beleid

Hogere administratieve beroepen (automatisering ed.)

- informatica ontwikkelen, adviseren

- informatica beheren, verwerken

- leidinggeven aan uitvoerenden zonder beleid

Hogere commerciële beroepen ed.

- handel drijven in het groot

- adviseren; commercieel, economisch

- onderzoeken; cijfermatig

Hogere sociaal-maatschappelijke beroepen

- agogisch, maatschappelijk begeleiden

- personeelswerk verrichten

- beleid voorbereiden

Docenten taalkundige, culturele vakken (1e gr. en WO)

- les geven, doceren

- onderzoeken; niet cijfermatig

- schrijven, redigeren, vertalen

Wetenschappelijke wiskundige, natuurwetenschappelijke beroepen

- onderzoeken; cijfermatig

- schrijven, redigeren, vertalen

- leidinggeven aan uitvoerenden zonder beleid

Wetenschappelijke (para)medische beroepen (excl. technisch) ed. - genezen mensen

- onderzoeken; cijfermatig

- dieren genezen

Wetenschappelijke juridische, bestuurlijke beroepen

- adviseren; juridisch, fiscaal

- beleid voorbereiden

- leidinggeven aan uitvoerenden zonder beleid

Managers (wetenschappelijk werk- en denkniveau)

- leidinggeven aan leidinggevenden en beleid

- leidinggeven aan uitvoerenden en beleid 
Wanneer voor een bepaald beroep minimaal één werksoort fysiek belastend is, wordt het desbetreffende beroep als fysiek belastend getypeerd. In Bijlage A wordt een overzicht gegeven van de typeringen van de diverse werksoorten. Wanneer deze informatie wordt geaggregeerd op beroepsgroepniveau, kan worden aangegeven welk percentage van de werkenden in deze beroepsgroep fysiek belastend werk verricht.

Tabel 3.7

Percentage werkenden met fysiek belastende werkzaamheden per beroepsgroep, 1994

Beroepsgroep $\quad \%$

$\begin{array}{lr}\text { Elementaire technische beroepen } & 88 \\ \text { Elementaire verzorgende beroepen } & 98 \\ \text { Lagere algemeen agrarische beroepen } & 95 \\ \text { Lagere bouwkundige beroepen } & 100 \\ \text { Lagere algemene transportberoepen } & 68 \\ \text { Lagere verkoopberoepen } & 0 \\ \text { Middelbare werktuigbouwkundige beroepen e.d. } & 77 \\ \text { Middelbare procestechnische beroepen } & 31 \\ \text { Middelbare algemene (para)medische beroepen } & 75 \\ \text { Middelbare commerciële beroepen } & 0 \\ \text { Middelbare algemeen verzorgende beroepen } & 75 \\ \text { Docenten basisonderwijs, algemeen vormende vakken } & 0 \\ \text { Hogere bouwkundige, technische beveiligingsberoepen } & 0 \\ \text { Hogere algemene, verzorgende (para)medische beroepen } & 84 \\ \text { Hogere administratieve beroepen (automatisering ed.) } & 0 \\ \text { Hogere commerciële beroepen ed. } & 0 \\ \text { Hogere sociaal-maatschappelijke beroepen } & 0 \\ \text { Docenten taalkundige, culturele vakken (1e gr. en WO) } & 0 \\ \text { Wetenschappelijke wiskundige, natuurwetenschappelijke beroepen } & 0 \\ \text { Wetenschappelijke (para)medische beroepen (excl. technisch) ed. } & 0 \\ \text { Wetenschappelijke juridische, bestuurlijke beroepen } & 0 \\ \text { Managers (wetenschappelijk werk- en denkniveau) } & 0\end{array}$

$\mathrm{Bij}$ het typeren van de fysieke belasting van de onderscheiden werksooorten is overleg gevoerd met het CBS en het LDC. In het overleg met het CBS kwam naar voren dat ook de EBB en het Doorlopend Leefsituatie-onderzoek (DLO) van het CBS, mede gefinancierd door het Ministerie van Sociale Zaken en Werkgelegenheid, informatie verzamelen over diverse aspecten van de kwaliteit van het werk, waaronder de fysieke en geestelijke belastbaarheid van het werk: tillen, lawaai, beeldschermwerk, hoge tijdsdruk, verandering werkdruk e.d. Dit zou het ook mogelijk maken om in de toekomst de informatie over de fysieke en geestelijke belastbaarheid met behulp van de subjectieve methode direct te relateren aan de beroepsgroep (en de opleidingsachtergrond) van de werkenden.

Tabel 3.7 geeft een overzicht van het percentage werkenden in een bepaalde beroepsgroep dat werkzaam is in een fysiek belastend beroep. 
Duidelijk is het het dat met name degenen die werkzaam zijn in elementaire, lagere en middelbare beroepen fysieke werkzaamheden dienen te verrichten. Een duidelijke uitzondering onder de hogere beroepsgroepen is de beroepsgroep hogere algemene, verzorgende (para)medische beroepen, waarvan $84 \%$ met fysieke werkzaamheden wordt geconfronteerd.

\section{Kans op buitenwerk}

Bij de studie- en beroepskeuze is het voor sommigen ook van belang of men na het volgen van een bepaalde opleiding vooral binnen- of buitenwerk moet verrichten. Om de kans op buitenwerk in beeld te kunnen brengen zijn de 128 werksoorten onderverdeeld in:

- $\quad$ activiteiten die altijd binnen zullen plaatsvinden (bijvoorbeeld schrijven);

- activiteiten die geheel of gedeeltelijk binnen, maar ook buiten kunnen plaatsvinden (bijvoorbeeld schilderen);

- $\quad$ activiteiten die altijd buiten zullen plaatsvinden (bijvoorbeeld bosbouwwerk).

Ook deze indeling is in bijlage $A$ te vinden. Vervolgens zijn de beroepen met een werksoort die altijd buiten uitgevoerd zal worden, getypeerd als beroepen die ('zeker') geheel of gedeeltelijk buiten uitgeoefend worden. Bij de resterende beroepen is gekeken of er werksoorten verricht worden die mogelijk buiten worden uitgevoerd. Deze beroepen worden getypeerd als 'mogelijke buitenberoepen'. Ten slotte worden de beroepen met enkel binnen verrichte werksoorten getypeerd als beroepen waarin zeker niet buiten gewerkt zal worden.

De typering van de kans op buitenwerk kent duidelijk nog een aantal tekortkomingen. Zo zouden bepaalde werksoorten (bijvoorbeeld schilderen, onderhoudswerk verrichten, training geven) voor het ene beroep binnenwerkzaamheden kunnen betekenen, terwijl ze bij een ander beroep buitenwerk impliceren. Bovendien kan er geen uitspraak worden gedaan over het deel van de werktijd dat in een bepaald beroep gemiddeld buiten wordt verricht. Ook hier zou de typering verbeterd kunnen worden, wanneer gebruik gemaakt zou kunnen worden van aan beroepsgroepen relateerbare informatie uit de EBB. Vooralsnog is een dergelijke vraag echter nog niet opgenomen in de EBB-vragenlijst.

Wanneer de beroepeninformatie wordt geaggregeerd op beroepsgroepniveau, kan worden aangegeven welk percentage van de werkenden in deze beroepsgroep zeker buiten werkt en welk percentage mogelijk buitenwerk verricht. Tabel 3.8 geeft een overzicht van de kans op buitenwerk bij een aantal beroepsgroepen. De tabel laat zien dat er slechts weinig beroepen bestaan waarvan de beoefenaars zeker met buitenwerkzaamheden geconfronteerd worden. Dit geldt eigenlijk alleen voor agrarische beroepen tot middelbaar niveau, voor de elementaire en lagere transportberoepen en voor de lagere weg- en waterbouwkundige beroepen. De 
relatief hoge kans op mogelijk buitenwerk bij de lagere bouwkundige en middelbare werktuigbouwkundige beroepen wordt veroorzaakt door respectievelijk het vaak voorkomen van 'elementaire' technische werkzaamheden als timmeren, schilderen en metselen bij de eerste groep, en monteer- en onderhoudswerkzaamheden bij de tweede beroepsgroep. Dit zijn namelijk werkzaamheden die zowel binnen als buiten voor kunnen komen.

Tabel 3.8

Kans op buitenwerk per beroepsgroep, 1994

Buitenwerk

\begin{tabular}{lcc} 
Beroepsgroep & $\begin{array}{c}\text { Zeker } \\
\%\end{array}$ & $\begin{array}{c}\text { Mogelijk } \\
\%\end{array}$ \\
\hline Elementaire technische beroepen & 4 & 41 \\
Elementaire verzorgende beroepen & 0 & 22 \\
Lagere algemeen agrarische beroepen & 95 & 4 \\
Lagere bouwkundige beroepen & 5 & 82 \\
Lagere algemene transportberoepen & 67 & 22 \\
Lagere verkoopberoepen & 0 & 2 \\
Middelbare werktuigbouwkundige beroepen e.d. & 0 & 87 \\
Middelbare procestechnische beroepen & 0 & 27 \\
Middelbare algemene (para) medische beroepen & 0 & 1 \\
Middelbare commerciële beroepen & 0 & 3 \\
Middelbare algemeen verzorgende beroepen & 0 & 4 \\
Docenten basisonderwijs, algemeen vormende vakken & 0 & 0 \\
Hogere bouwkundigen, technische beveiligingsberoepen & 0 & 29 \\
Hogere algemene, verzorgende (para) medische beroepen & 0 & 16 \\
Hogere administratieve beroepen (automatisering e.d.) & 0 & 4 \\
Hogere commerciële beroepen e.d. & 0 & 16 \\
Hogere sociaal-maatschappelijke beroepen & 0 & 13 \\
Docenten taalkundige, culturele vakken (1e gr. en wO) & 0 & 0 \\
Wetenschappelijke wiskundige, natuurwetenschappelijke & 0 & 7 \\
beroepen & 0 & 0 \\
Wetenschappelijke (para) medische beroepen & 0 & 18 \\
(excl. technisch) e.d. & 0 & \\
Wetenschappelijke juridische, bestuurlijke beroepen & 0 & 0 \\
Managers (wetenschappelijk werk- en denkniveau & 0 &
\end{tabular}





\section{Typering van het beroependomein per opleidingstype}

\subsection{Inleiding}

De in het vorige hoofdstuk beschreven kenmerken van de diverse onderscheiden beroepsgroepen maken het mogelijk om per opleidingstype een nadere karakterisering te geven van het beroependomein van de werkenden met de desbetreffende opleidingsachtergrond. Op deze wijze kan voor elk opleidingstype een beeld worden verkregen van de beroepsniveaus en -terreinen, waarin men met de desbetreffende opleiding zoal terecht komt, de aard van de te verrichten werkzaamheden, de vereiste vaardigheden en de kwaliteit van het werk. In dit hoofdstuk zal achtereenvolgens op deze aspecten van het werk worden ingegaan.

\subsection{Beroepsniveau}

Evenals bij de beroepsgroepen is een aantal opleidingstypen geselecteerd die een globale indruk geven van de bestaande verschillen in het beroependomein van opleidingen. Tabel 4.1 bevat de niveautypering van deze 26 opleidingstypen. De percentages geven de verdeling over de betreffende niveau-groepen aan in de werkgelegenheid in 1994 op basis van de EBB.

Voor de lagere opleidingsniveaus in de tabel geldt dat de werkgelegenheid vaak sterk verdeeld is over de niveaugroepen. De werkgelegenheid van ongediplomeerden (alleen basisonderwijs) blijkt voor de helft op MBO-niveau te liggen, terwijl degenen met deze opleidingsachtergrond daarnaast verdeeld zijn over een drietal bredere groepen die basisonderwijs, VBO en MBO combineren. Een specifiek beroepssegment op basisonderwijsniveau blijkt niet te bestaan. Ook voor het MAVO en de drie VBO-opleidingen in de tabel blijkt de werkgelegenheid sterk verdeeld te zijn over verschillende beroepsniveaus. Alleen voor VBO-bouwtechiek is vrijwel de helft van de werkgelegenheid ook daadwerkelijk op VBO-niveau. Bij al deze opleidingen blijkt echter met name ook het MBO-niveau een belangrijke bron van werkgelegenheid te zijn.

De werkgelegenheid voor alle zeven MBO-opleidingen die in de tabel worden onderscheiden blijkt de meerderheid van de werkgelegenheid in de groep 'MBO of lager' gesitueerd te zijn. Deze groep omvat het VBO/MBO-domein, alsmede het $\mathrm{BO} / \mathrm{VBO} / \mathrm{MBO}$-domein. Het is opmerkelijk dat de MBO-opleidingen in tegenstelling tot basisonderwijs, MAVO en de VBO-opleidingen slechts een geringe vertegenwoordiging hebben in het specifieke MBO-domein. 
Voor de meeste HBO- en WO-opleidingen geldt wel dat een meerderheid van de werkgelegenheid geconcentreerd is in respectievelijk het specifieke HBO- en WOdomein. Alleen WO econom(etr)ie en accountancy heeft in het WO-domein slechts $33 \%$ van de werkgelegenheid en is relatief sterk vertegenwoordigt in het gecombineerde HBOMO-domein. Voor het hogere onderwijs blijken de beroepsniveaus van $\mathrm{MBO}$ en lager van slechts geringe betekenis te zijn. Bij het HBO is het aandeel in deze niveaugroepen doorgaans lager dan $20 \%$. Alleen HBO sociaal-cultureel heeft een iets groter aandeel in de beroepen op het niveau 'MBO of lager'. Voor de WO-opleidingen komt dit aandeel niet boven de $10 \%$. Ook op het HBO-niveau is alleen bij WO elektrotechniek en technische informatica en bij WO sociaal-cultureel een aanmerkelijk hoger aandeel werkzaam.

\subsection{Beroepsterrein}

De werkgelegenheid van een opleidingstype kan zich over een groot aantal beroepsterreinen verdelen. Omdat echter verwacht kan worden dat voor de meeste opleidingstypen met name het eigen 'vakspecifieke' domein van belang is, is in tabel 4.2 achtereenvolgens aangeven welk deel van de werkgelegenheid in dit eigen domein werkzaam is, welk deel werkzaam is in een domein dat de eigen richting combineert met een andere richting (het gedeeld domein) en welke deel in andere domeinen werkzaam is. Deze laatste categorie wordt aangeduid als het uitwijkdomein. In de laatste kolom wordt aangeven welk domein binnen dit uitwijksegment het grootste belang heeft voor het betreffende opleidingstype.

Niet alle opleidingstypen blijken hun belangrijkste deel van de werkgelegenheid in het eigen domein te vinden. Voor basisonderwijs, MAVO, VBO verzorging en MBO/LLW handel is dit percentage uitzonderlijk laag. Deze opleidingstypen zijn wel redelijk vertegenwoordigd in het gedeeld domein, maar opvallend is vooral de grote vertegenwoordiging in het uitwijkdomein. Hun werkgelegenheid is sterk gespreid over de verschillende terreinen. Dit blijkt in de tabel uit het feit dat het belangrijkste uitwijkterrein slechts een gering deel van het totale uitwijkdomein betreft.

Bij veel andere opleidingstypen schommelt het percentage dat werkzaam is in het vakspecifieke domein rond de $50 \%$. Zeer sterk op het vakspecifieke domein gericht zijn MBO/LLW bouwkunde, HBO verpleging en paramedisch en HBO accountancy en WO dier-, genees-, en tandheelkunde. 


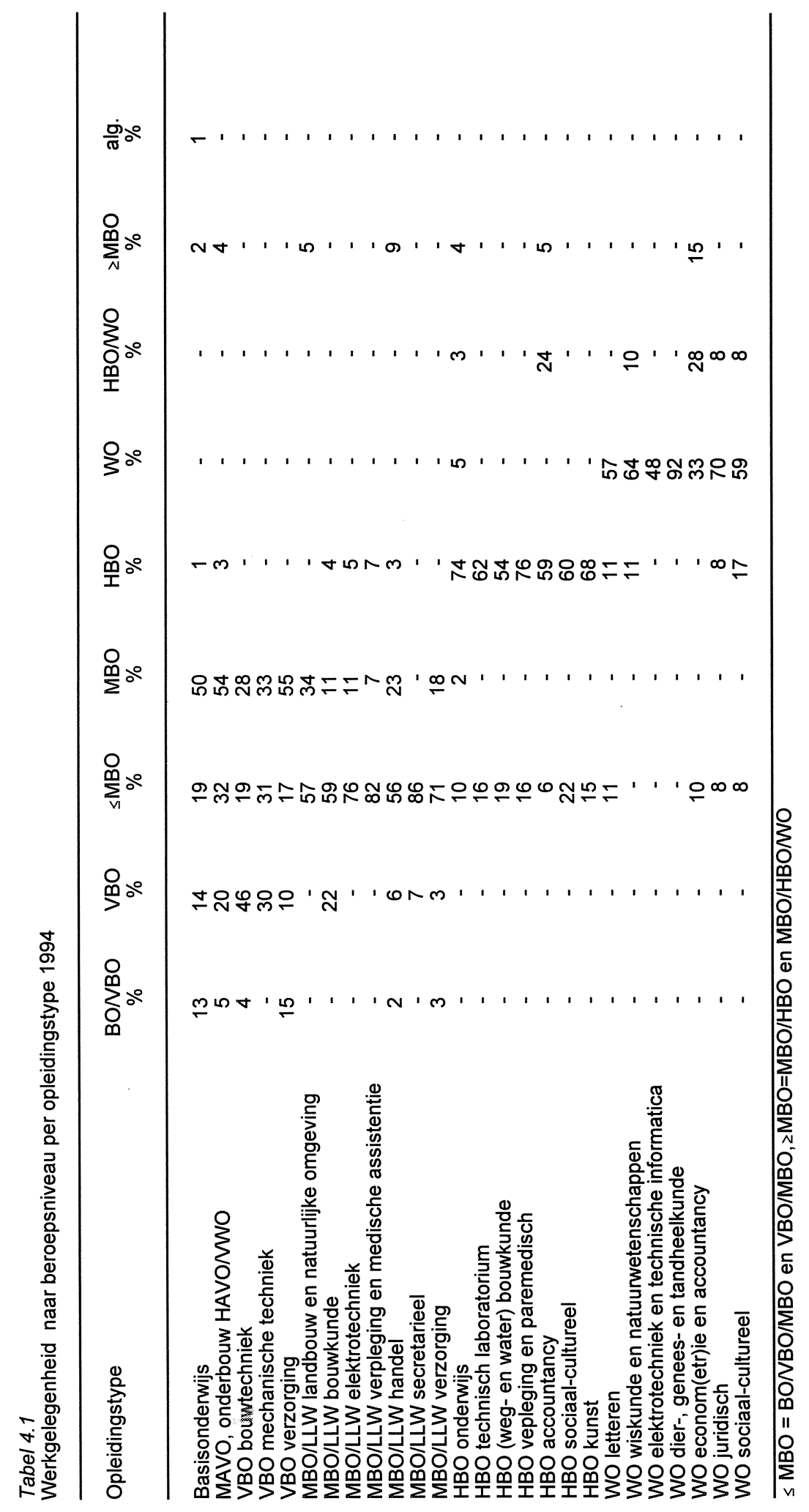




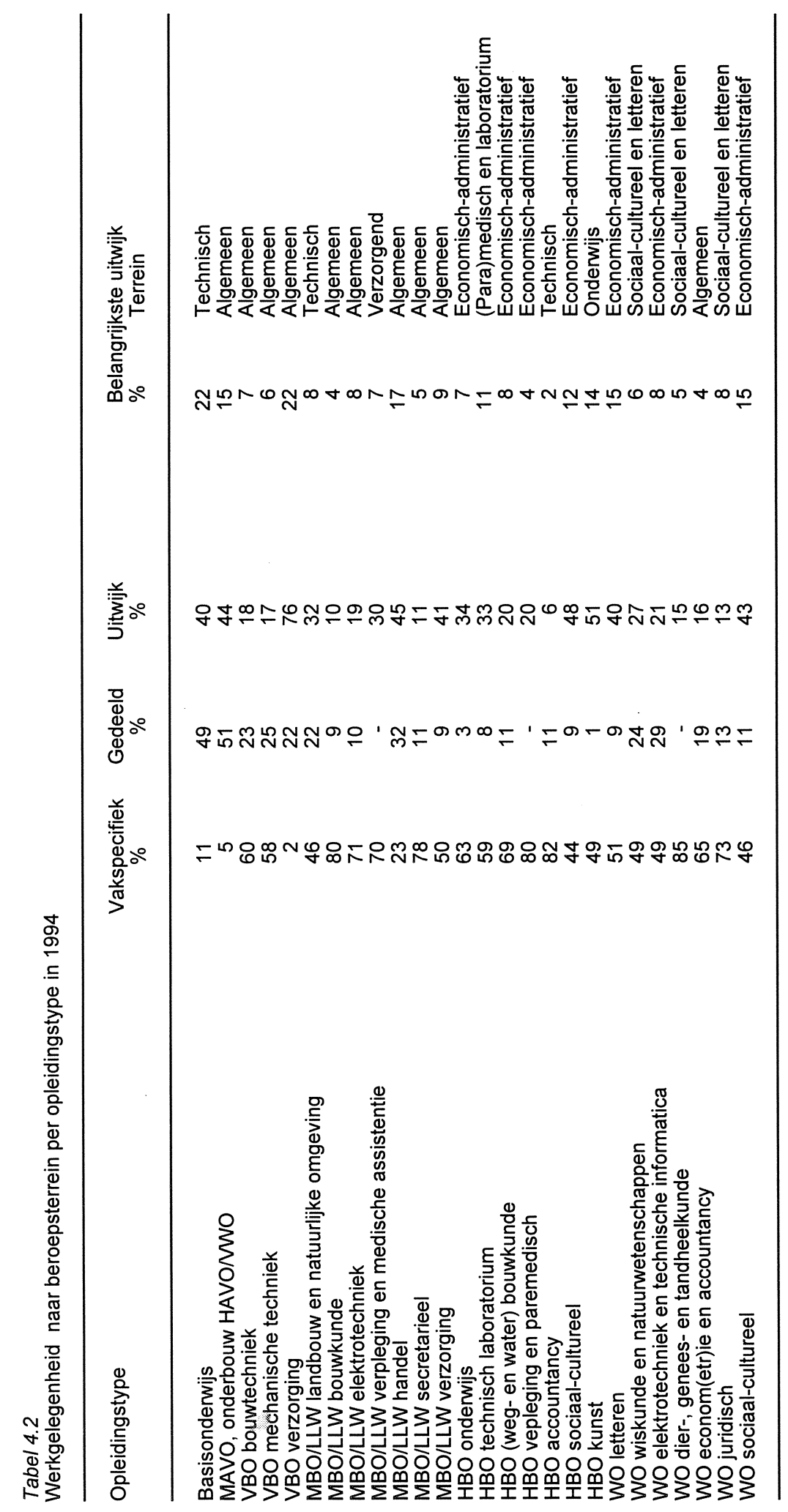




\subsection{Vereiste vaardigheden}

Analoog aan de belangrijkste werksoorten per opleidingscategorie die afgeleid zijn van de werksoorten per beroepsgroep, kunnen tevens de vereiste vaardigheden per opleiding worden afgeleid van de vaardigheden per beroepsgroep. Tabel 4.3 toont voor een selectie van opleidingstypen de mate waarin de verschillende vaardigheden vereist zijn in het beroependomein waarin degenen met de desbetreffende opleidingsachtergrond werkzaam zijn. Daar waar de lager en middelbaar opgeleiden relatief veel baat hebben bij vakspecifieke vaardigheden, hebben de hoger en wetenschappelijk opgeleiden verhoudingsgewijs veel belang bij communicatieve vaardigheden. Volgens verwachting zijn managementvaardigheden meer vereist voor de hoger opgeleiden dan voor degenen met een lager opleidingsniveau. Duidelijk is dat ook de meerderheid van degenen die slechts het basisonderwijs hebben afgerond, dienen te beschikken over (vakspecifieke) vaardigheden; slechts $14 \%$ van hen komt in een beroep terecht waarvoor geen direkt aantoonbare vaardigheden worden vereist.

\subsection{Aard van de werkzaamheden}

Op basis van de verdeling van de werkenden met een bepaalde opleidingsachtergrond over de diverse beroepsgroepen, kan ook een indicatie worden verkregen van de voor de desbetreffende opleidingscategorie belangrijkste werksoorten. In principe zou meer exacte informatie kunnen worden verkregen wanneer een directe relatie zou kunnen worden gelegd met de beroepen waarin arbeidskrachten met een bepaalde opleidingsachtergrond werkzaam zijn. Daar dit vooralsnog niet mogelijk was, is noodgedwongen de aggregatieslag gemaakt naar het beroepsgroepniveau. Voorzover mensen met een bepaalde opleidingsachtergrond binnen een beroepsgroep hoofdzakelijk in een specifiek beroep werkzaam zijn, kan er daardoor een vertekend beeld ontstaan van de te verrichten werksoorten.

Uit de lijst met opleidingstypen met meest vookomende werksoorten, zoals weergegeven in tabel 4.4, valt af te lezen dat VBO'ers en in mindere mate MBO'ers in de richting Verzorging veel (noodgedwongen) uitwijkgedrag vertonen naar verkoop- en schoonmaakberoepen. Daarentegen verrichten de gediplomeerden van bijvoorbeeld het MBO/LLW landbouw en natuurlijke omgeving hoofdzakelijk werkzaamheden in de eigen vakrichting (veeteeltwerk, tuinbouwwerk en landbouwwerk). Het 'smalle' beroependomein voor het HBO onderwijs wordt weerspiegeld in de $69 \%$ van de dusdanig opgeleiden die zich in hun beroep daadwerkelijk met lesgeven bezighouden. 


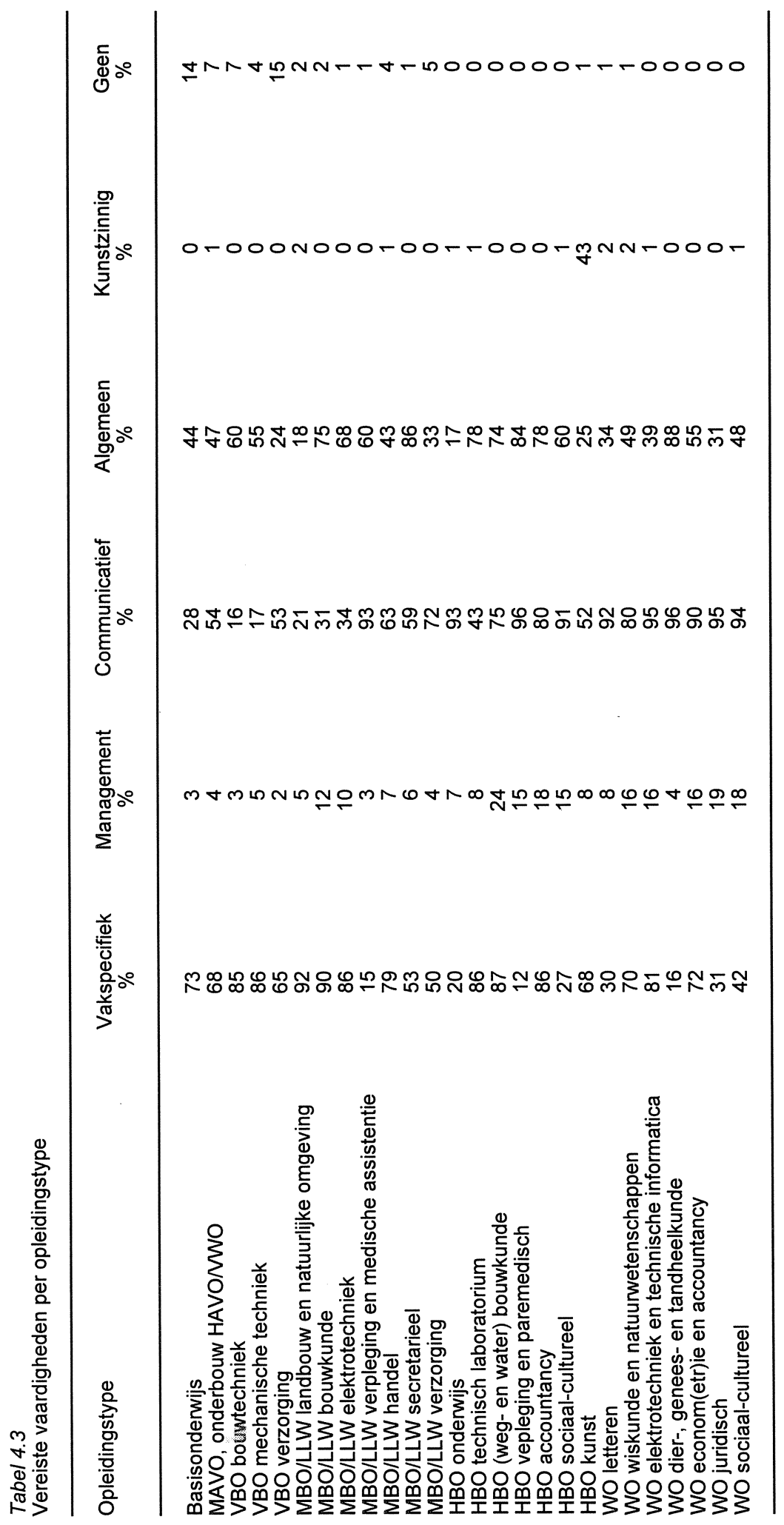


Tabel 4.4

Belangrijkste werksoorten per opleidingstype, 1994

Opleidingstype

- werksoort

Basisonderwijs

- schoonmaken huishoudelijk, kantoor

- verkopen (excl. vertegenwoordigen)

- bezorgen

- bezorgen

MAVO, onderbouw HAVONWO

- verkopen (excl. vertegenwoordigen)

- administreren; cijfermatig

- administreren; teksten

VBO bouwtechniek

- timmeren

- schilderen, verven, spuiten

- metselen, voegen, tegelzetten

VBO mechanische techniek

- produktiemachines, -apparatuur bedienen

- lassen, snijden, solderen

- bezorgen

VBO verzorging

- verkopen (excl. vertegenwoordigen)

- schoonmaken huishoudelijk, kantoor

- afrekenen

MBO/LLW landbouw en natuurlijke omgeving

- veeteeltwerk verrichten

29

- tuinbouwwerk verrichten

23

- landbouwwerk verrichten (excl. veeteelt

MBO/LLW bouwkunde

- timmeren

- verkopen (excl. vertegenwoordigen)

- monteren: leidingen (installatietechniek)

MBO/LLW elektrotechniek

- monteren, repareren: sterkstroom

- monteren, repareren: zwakstroom

- monteren, repareren: elektronica

- verplegen

29

- verzorgen, helpen mensen

MBO/LLW hande

- verkopen (excl. vertegenwoordigen)

- inkopen

- administreren; cijfermatig

MBO/LLW secretarieel

- administreren; cijfermatig

- secretarieel werk verrichten

- administreren, teksten

$\mathrm{MBO} / \mathrm{LLW}$ verzorging

- verzorgen, helpen mensen

- verkopen (excl. vertegenwoordigen) 
Tabel 4.4 (vervolg)

Belangrijkste werksoorten per opleidingstype, 1994

Opleidingstype

- werksoort

- schoonmaken huishoudelijk, kantoor

$\mathrm{HBO}$ onderwijs

- les geven, doceren

- leidinggeven aan leidinggevenden en beleid

- verkopen (excl. vertegenwoordigen)

HBO technisch laboratorium

- analistenwerk

- onderzoeken; cijfermatig

- administreren; cijfermatig

- HBO (weg- en water) bouwkunde

- ontwerpen, construeren

- leidinggeven aan uitvoerenden zonder beleid

- werkvoorbereiden, werk coördineren

$\mathrm{HBO}$ vepleging en paremedisch

- verplegen

- therapeutisch begeleiden (fysiek)

- leidinggeven aan uitvoerenden zonder beleid

HBO accountancy

- administreren; cijfermatig

- adviseren; juridisch, fiscaal

- inspecteren

HBO sociaal-cultureel

- agogisch, maatschappelijk begeleiden

20

- personeelswerk verrichten

- leidinggeven aan uitvoerenden zonder beleid

HBO kunst

- beeldende kunst beoefenen

- les geven, doceren

- werkvoorbereiden, werk coördineren

WO letteren

- les geven, doceren

- schrijven, redigeren, vertalen

- leidinggeven aan uitvoerenden zonder beleid

WO wiskunde en natuurwetenschappen

- onderzoeken; cijfermatig

- les geven, doceren

- schrijven, redigeren, vertalen

WO elektrotechniek en technische informatica

- informatica ontwikkelen, adviseren

- ontwerpen, construeren

- leidinggeven aan uitvoerenden zonder beleid

WO dier-, genees- en tandheelkunde

- genezen mensen

- onderzoeken; cijfermatig

- schrijven, redigeren, vertalen

WO econom(etr)ie en accountancy

- administreren; cijfermatig 
Tabel 4.4 (vervolg)

Belangrijkste werksoorten per opleidingstype, 1994

Opleidingstype

- werksoort

- inspecteren

WO juridisch

- adviseren; juridisch fiscaa

- beleid voorbereiden

- leidinggeven aan uitvoerenden zonder bel

40

WO sociaal-cultureel

- les geven, doceren

- schrijven, redigeren, vertalen

- agogisch, maatschappelijk begeleiden

12

16

12

Tabel 4.4 geeft een overzicht van de voor de diverse opleidingstypen belangrijkste werksoorten. Daarbij zijn voor elk opleidingstype telkens de belangrijkste drie werksoorten vermeld. Uit de tabel blijkt dat de mate waarin de belangrijkste werksoorten dominant zijn sterk verschilt tussen de verschillende opleidingstypen.

\subsection{Kwaliteit van het werk}

In hoeverre men met een bepaalde opleidingsachtergrond kans heeft op fysieke werkzaamheden tijdens de beroepsuitoefening komt naar voren in tabel 4.5, waar voor een aantal opleidingstypen de kans op fysiek werk is weergegeven. Wederom is hierbij gebruik gemaakt van de resultaten per beroepsgroep en de gegevens betreffende het beroependomein per opleidingstype uit de Enquête BeroepsBevolking van het CBS. De kans op fysiek belastend werk neemt duidelijk af bij het toenemen van het opleidingsniveau. Daarnaast hebben met name degenen die een opleiding in de richting verpleging en paramedisch, en in de verzorgende richting hebben afgerond een verhoogde kans op fysiek belastend werk.

Tot slot toont tabel 4.6 per opleidingstype de kans op het zeker en op het mogelijk verrichten van buitenwerk tijdens de beroepsuitoefening. Behalve voor de opleiding MBO/LLW landbouw en natuurlijke omgeving is de kans op het zeker in aanraking komen met buiten-werkzaamheden voor geen ander opleidingstype uit deze selectie aanzienlijk. Wel blijken veel opleidingen een reële kans te geven op mogelijkerwijs buitenwerk. Om meer grip te krijgen op deze 'mogelijke' kans, kan het zinvol zijn om per beroep de werksoorten die deze mogelijkheid verschaffen nader te beschouwen.

Uit de lijst met opleidingstypen met meest vookomende werksoorten, zoals weergegeven in tabel 4.4, valt af te lezen dat VBO'ers en in mindere mate MBO'ers in de richting Verzorging veel (noodgedwongen) uitwijkgedrag vertonen naar verkoop- en schoonmaakberoepen. Daarentegen verrichten de gediplomeerden van bijvoorbeeld het MBO/LLW landbouw en natuurlijke omgeving hoofdzakelijk 
werkzaamheden in de eigen vakrichting (veeteeltwerk, tuinbouwwerk en landbouwwerk). Het 'smalle' beroependomein voor het HBO onderwijs wordt weerspiegeld in de $69 \%$ van de dusdanig opgeleiden die zich in hun beroep daadwerkelijk met lesgeven bezighouden.

Tabel 4.5

Kans op fysiek belastend werk per opleidingstype

Opleidingstype

Kans op

belastend werk

$\%$

Basisonderwijs

MAVO, onderbouw HAVOMWO

VBO bouwtechniek

VBO mechanische techniek

VBO verzorging

MBO/LLW landbouw en natuurlijke omgeving

MBO/LLW bouwkunde

MBO/LLW elektrotechniek

MBO/LLW verpleging en medische assistentie

MBO/LLW handel

MBO/LLW secretariee

MBO/LLW verzorging

$\mathrm{HBO}$ onderwijs

$\mathrm{HBO}$ technisch laboratorium

HBO (weg-en water) bouwkunde

$\mathrm{HBO}$ verpleging en paramedisch

HBO accountancy

HBO sociaal-cultureel

HBO kunst

WO letteren

WO wiskunde en natuurwetenschappen

WO elektrotechniek en technische informatica

WO dier-, genees- en tandheelkunde

WO econom(etr)ie en accountancy

WO juridisch

WO sociaal-cultureel

68

37
79

74

59

75

59

71

23

61

6

12

12
71

1

13

26

7

2

5 
Tabel 4.6

Kans op beroep met buitenwerk per opleidingstype, 1994

\begin{tabular}{lcc}
\hline Opleidingstype & $\begin{array}{c}\text { Zeker } \\
\%\end{array}$ & Kans op buitenwerk \\
& & $\begin{array}{c}\text { Mogelijk } \\
\%\end{array}$ \\
\hline Basisonderwijs & 20 & 31 \\
MAVO, onderbouw HAVO/NWO & 10 & 20 \\
VBO bouwtechniek & 16 & 56 \\
VBO mechanische techniek & 15 & 50 \\
VBO verzorging & 11 & 20 \\
MBO/LLW landbouw en natuurlijke omgeving & 68 & 11 \\
MBO/LLW bouwkunde & 6 & 67 \\
MBO/LLW elektrotechniek & 2 & 51 \\
MBO/LLW verpleging en medische assistentie & 1 & 6 \\
MBO/LLW handel & 7 & 17 \\
MBO/LLW secretarieel & 1 & 7 \\
MBO/LLW verzorging & 3 & 13 \\
HBO onderwijs & 1 & 6 \\
HBO technisch laboratorium & 0 & 9 \\
HBO (weg- en water) bouwkunde & 2 & 34 \\
HBO vepleging en paremedisch & 1 & 15 \\
HBO accountancy & 0 & 37 \\
HBO sociaal-cultureel & 0 & 15 \\
HBO kunst & 1 & 40 \\
WO letteren & 1 & 13 \\
WO wiskunde en natuurwetenschappen & 2 & 14 \\
WO elektrotechniek en technische informatica & 0 & 16 \\
WO dier-, genees- en tandheelkunde & 0 & 8 \\
WO econom(etr)ie en accountancy & 0 & 29 \\
WO juridisch & 0 & 16 \\
WO sociaal-cultureel & 0 & 13 \\
& & \\
\hline & & \\
\hline
\end{tabular}




$$
\ldots
$$




\title{
5 Enkele combinaties van typeringen
}

\author{
5.1 Inleiding
}

In de vorige hoofdstukken is het beroependomein van opleidingstypen getypeerd vanuit verschillende dimensies. Door deze meerdimensionale aanpak wordt een genuanceerd beeld van het beroependomein geschetst. De verschillende invalshoeken bieden echter ook de mogelijkheid om combinaties in beeld te brengen die inzicht geven in de samenhang tussen de aard van het werk en de soort kwalificaties die vereist zijn. In dit hoofdstuk worden bij wijze van voorbeeld twee voorbeelden gegeven waarin een dergelijke combinatie wordt gelegd. In paragraaf 5.2 gaat het om de mate waarin onder lager en middelbaar opgeleiden fysiek werk voorkomt in het vakspecifieke domein en in paragraaf 5.3 wordt voor hoger opgeleiden een analyse gemaakt van de relatie tussen vereiste vaardigheden en het terrein van de werkzaamheden.

\subsection{Fysieke belasting op vakspecifiek en uitwijksegment bij lager en middelbaar opgeleiden}

In paragraaf 4.6 kwam reeds naar voren dat met name lager en middelbaar opgeleiden relatief vaak te maken krijgen met fysiek belastend werk. Met name voor degenen die in hun functioneren beperkingen kennen qua fysieke belasting is het derhalve van belang inzicht te hebben in het belang van fysieke kwaliteiten voor de beroepsuitoefening. Interessant is hierbij om na te gaan of de hoge mate waarin fysiek belastende werkzaamheden voorkomen, voorkomt uit de vakspecifieke werkzaamheden die men verricht, of dat juist de werkzaamheden in het uitwijkdomein een hoge belasting opleveren.

Tabel 5.1 geeft de kans op fysiek belastend werk voor de drie onderscheiden domeinen. Voor basisonderwijs, MAVO en de VBO-opleidingen blijkt dat voor zover er sprake is van een vakspecifiek domein van enige betekenis, met name hier de kans op fysiek zwaar werk hoog is. Alleen bij VBO consumptieve techniek en VBO verkoop en handel komt fysieke belasting in het eigen domein respectievelijk aanzienlijk minder en vrijwel niet voor. Echter ook in het gedeeld domein en in het uitwijkdomein is er bij de meeste opleidingstypen nog sprake van een aanzienlijke kans op fysieke belasting. Alleen bij VBO bewaking is dit percentage laag.

Ook op MBO-niveau hebben de technische opleidingstypen een hoge kans op fysiek belastend werk in hun vakspecifieke beroependomein. Alleen bij technisch laboratorium is deze kans zeer laag, terwijl voor weg- en waterbouwkunde, consumptieve techniek en procestechniek de kans op fysiek belastend werk slechts gering is. Van de niet-technische richtingen op MBO-niveau zijn met name verpleging en medische assistentie, verzorging en horeca en uiterlijke verzorging 
fysiek erg belastend in het vakspecifieke domein. Voor de meeste MBO-opleidingen is daarentegen het werk in het uitwijkdomein veel minder fysiek belastend. De hoogste kans op belastend werk in het uitwijkdomein wordt gevonden bij verpleging en medische assistentie en bij MBO/LLW administratief en secretarieel.

Tabel 5.1

Kans op fysiek belastend werk per opleidingstype op vakspecifiek en uitwijksegment

\begin{tabular}{lccc}
\hline Opleidingstype & vakspecifiek & $\substack{\text { gedeeld } \\
\%}$ & $\substack{\% \\
\%}$
\end{tabular}

Basisonderwijs

Mavo, onderbouw HAVO/MWO

VBO landbouw en natuurlijke omgeving

VBO bouwtechniek

VBO installatietechniek

VBO mechanische techniek

VBO motorvoertuigentechniek

VBO elektrotechniek

VBO grafische techniek

VBO grafische techniek
VBO consumptieve techniek

VBO consumptieve techniek
VBO textiel- en ledertechniek

VBO haven en vervoer

VBO administratie

VBO verkoop en handel

VBO verzorging

VBO bewaking

HAVONWO bovenbouw

MBO/LLW landbouw en natuurlijke omgeving

MBO technisch laboratorium

MBO/LLW bouwkunde

MBO/LLW weg-en waterbouwkunde

MBO/LLW metaalkunde

MBO/LLW fijnmechanische techniek

MBO/LLW werktuigbouwkunde

MBO/LLW motorvoertuigentechniek

MBO/LLW elektrotechniek

MBO/LLW grafische techniek

MBO/LLW consumptieve techniek

MBO/LLW procestechniek

MBO/LLW textiel- en ledertechniek

MBO/LLW haven en vervoer

$\mathrm{MBO} / \mathrm{LLW}$ verpleging en medische assistentie

MBO/LLW medisch laboratorium

MBO/LLW handel

MBO/LLW administratief

MBO toerisme en recreatie

MBO/LLW commercieel

MBO/LLW secretarieel

MBO bestuurlijk-juridisch

MBO sociaal-culturee

MBO/LLW verzorging

MBO/LLW horeca en uiterlijke verzorging

MBO politie en defensie

\begin{tabular}{|c|c|c|}
\hline $\begin{array}{l}92 \\
91 \\
96 \\
90 \\
78 \\
82 \\
78 \\
78\end{array}$ & $\begin{array}{l}69 \\
42 \\
95 \\
75 \\
- \\
71 \\
70 \\
67\end{array}$ & $\begin{array}{r}59 \\
25 \\
57 \\
43 \\
49 \\
32 \\
26\end{array}$ \\
\hline $5 \overline{-}$ & $\overline{-}$ & 63 \\
\hline 50 & 65 & $\begin{array}{l}03 \\
54\end{array}$ \\
\hline - & 69 & - \\
\hline 3 & 6 & 56 \\
\hline - & 6 & 50 \\
\hline - & 92 & 49 \\
\hline - & 0 & - \\
\hline $\begin{array}{l}94 \\
92\end{array}$ & $\begin{array}{l}35 \\
95\end{array}$ & $\begin{array}{l}15 \\
36\end{array}$ \\
\hline 2 & $=$ & \\
\hline 72 & 55 & 27 \\
\hline 78 & $5 \overline{7}$ & 24 \\
\hline 80 & $\overline{-}$ & $=$ \\
\hline $\begin{array}{l}66 \\
75\end{array}$ & $\begin{array}{l}45 \\
57\end{array}$ & $\begin{array}{l}15 \\
13\end{array}$ \\
\hline 73 & 38 & 13 \\
\hline $\begin{array}{l}55 \\
32\end{array}$ & - & 14 \\
\hline $\begin{array}{l}32 \\
42\end{array}$ & 62 & 32 \\
\hline 42 & 62 & 36 \\
\hline 65 & 50 & 8 \\
\hline 81 & - & 45 \\
\hline 19 & - & 16 \\
\hline 2 & 5 & 47 \\
\hline 3 & 2 & 37 \\
\hline ? & 11 & $\overline{-}$ \\
\hline 4 & $\frac{2}{5}$ & $\begin{array}{l}26 \\
46\end{array}$ \\
\hline 2 & 2 & 19 \\
\hline & - & 40 \\
\hline 75 & 89 & 38 \\
\hline 75 & 72 & 27 \\
\hline 7 & 0 & 40 \\
\hline
\end{tabular}

5.3 Vereiste vaardigheden op vakspecifiek en uitwijksegment bij hoger opgeleiden

Als tweede voorbeeld voor het combineren van verschillende dimensies van de typering van het beroependomein, wordt in deze paragraaf een verband gelegd tussen het al dan niet werken in het vakspecifieke domein en de vereiste 
vaardigheden. De analyse richt zich op hoger opgeleiden. Verwacht zou kunnen worden dat bepaalde vaardigheden met name van belang zijn om goed te kunnen functioneren in het eigen vakspecifieke domein, terwijl andere, meer algemene vaardigheden ook in het uitwijkdomein van belang zijn.

Tabel 5.2

Vakspecifieke vaardigheden vereist op vakspecifiek en uitwijksegment

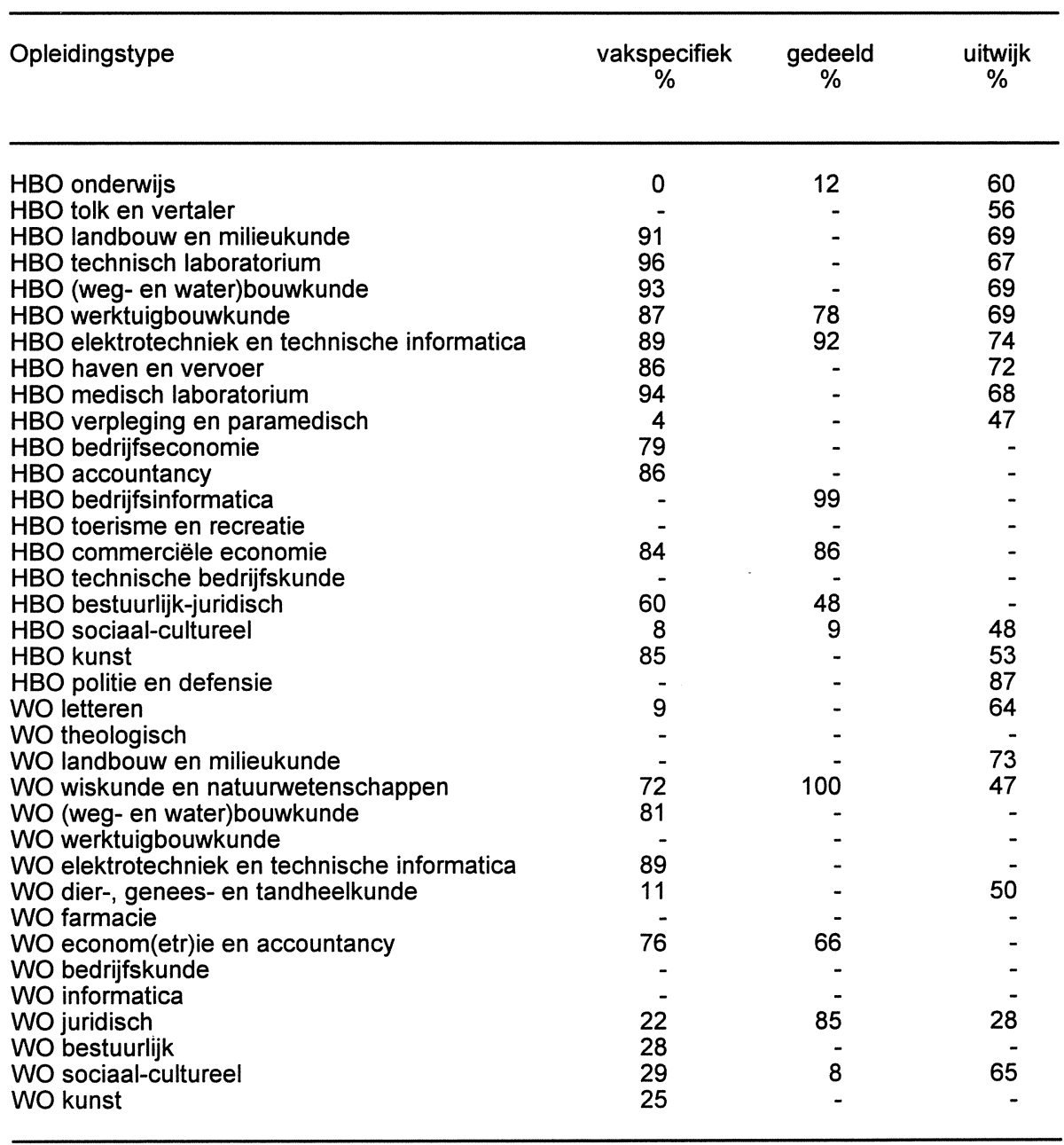

Tabel 5.2 gaat als eerste in op de vakspecifieke vaardigheden. Uit de tabel blijkt dat met name voor technische richtingen op HBO- en WO-niveau in het vakspecifieke domein vaak vakspecifieke vaardigheden worden vereist. Dit hangt samen met de nadruk op technische en kwantitatieve vaardigheden in de SBC'92. Hierdoor zijn bijvoorbeeld voor HBO verpleging en paramedisch en WO dier-, genees-, en tandheelkunde in het vakspecifieke domein vrijwel nooit vakspecifieke vaardigheden vereist. Voor een aantal economisch/administratieve richtingen zijn vakspecifieke 
vaardigheden wel een vereiste. Het gaat hier met name om kwantitatieve vaardigheden. Bij WO juridisch, WO bestuurlijk, WO sociaal-cultureel en WO kunst is er slechts in een beperkt aantal gevallen sprake van behoefte aan vakspecifieke vaardigheden.

Ook in het uitwijkdomein is met name bij de technische richtingen de behoefte aan vakspecifieke vaardigheden groot, zij het in een mindere mate dan in het vakspecifieke domein. Voor de meeste andere richtingen is in het uitwijkdomein het belang van vakspecifieke vaardigheden opvallend genoeg echter ook groot. Uitzonderingen zijn HBO onderwijs, HBO sociaal-cultureel en WO sociaal-cultureel.

Tabel 5.3

Management vaardigheden vereist op vakspecifiek en uitwijksegment

\begin{tabular}{lccc}
\hline Opleidingstype & vakspecifiek & gedeeld & uitwijk \\
$\%$ & & \\
\hline
\end{tabular}

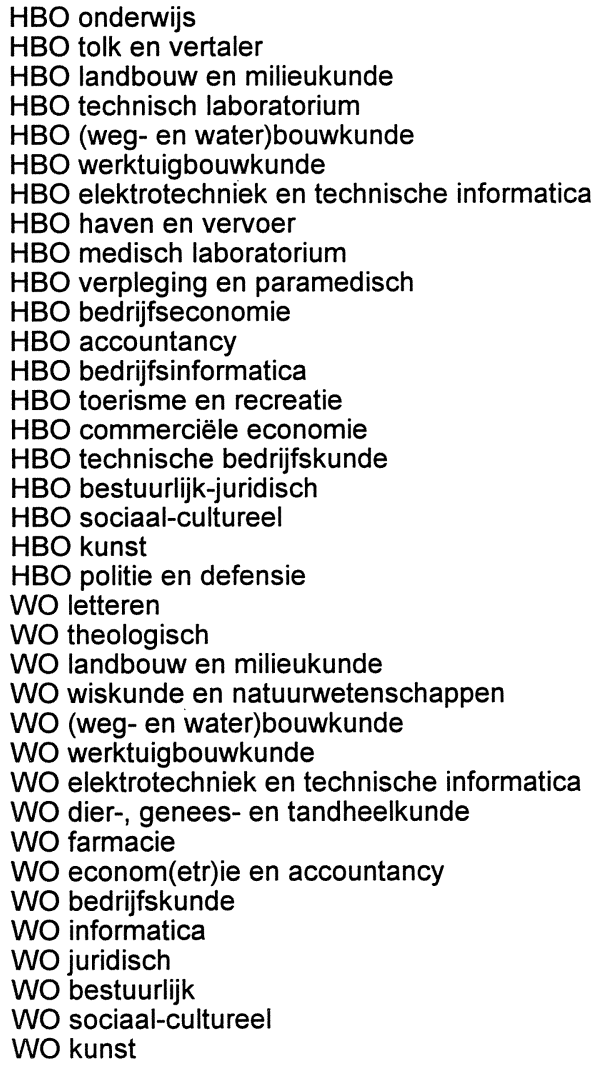

\begin{tabular}{|c|c|c|}
\hline 0 & 0 & 20 \\
\hline- & - & 8 \\
\hline 2 & - & 20 \\
\hline 7 & - & 4 \\
\hline 23 & - & 13 \\
\hline 28 & 45 & 9 \\
\hline 21 & 17 & 9 \\
\hline 35 & - & 8 \\
\hline 4 & - & 11 \\
\hline 14 & - & 21 \\
\hline 15 & - & - \\
\hline 16 & - & - \\
\hline- & 8 & - \\
\hline- & - & - \\
\hline 15 & 11 & - \\
\hline- & - & - \\
\hline 13 & 47 & - \\
\hline 13 & 39 & 14 \\
\hline 8 & - & 8 \\
\hline- & - & 50 \\
\hline 6 & - & 11 \\
\hline - & - & - \\
\hline- & - & 23 \\
\hline 10 & 42 & 11 \\
\hline 14 & - & - \\
\hline - & - & - \\
\hline 11 & - & - \\
\hline 2 & - & 21 \\
\hline - & - & - \\
\hline 10 & 45 & - \\
\hline- & - & - \\
\hline- & - & - \\
\hline 13 & 61 & 12 \\
\hline 12 & - & - \\
\hline 10 & 28 & 25 \\
\hline 4 & - & \\
\hline
\end{tabular}


Tabel 5.4

Communicatieve vaardigheden vereist op vakspecifiek en uitwijksegment

\begin{tabular}{|c|c|c|c|}
\hline Opleidingstype & $\begin{array}{c}\text { vakspecifiek } \\
\%\end{array}$ & $\begin{array}{c}\text { gedeeld } \\
\%\end{array}$ & $\underset{\%}{\text { uitwijk }}$ \\
\hline HBO onderwijs & 100 & 98 & 80 \\
\hline $\mathrm{HBO}$ tolk en vertaler & - & - & 74 \\
\hline HBO landbouw en milieukunde & 67 & - & 82 \\
\hline HBO technisch laboratorium & 21 & - & 72 \\
\hline HBO (weg-en water)bouwkunde & 70 & - & 82 \\
\hline HBO werktuigbouwkunde & 65 & 94 & 79 \\
\hline HBO elektrotechniek en technische informatica & 75 & 97 & 85 \\
\hline HBO haven en vervoer & 52 & - & 80 \\
\hline HBO medisch laboratorium & 48 & - & 64 \\
\hline HBO verpleging en paramedisch & 99 & - & 83 \\
\hline HBO bedrijfseconomie & 76 & - & - \\
\hline HBO accountancy & 80 & - & - \\
\hline HBO bedrijfsinformatica & - & 99 & - \\
\hline HBO toerisme en recreatie & - & - & - \\
\hline HBO commerciële economie & 91 & 84 & - \\
\hline HBO technische bedrijfskunde & - & $8+$ & - \\
\hline HBO bestuurlijk-juridisch & 80 & 95 & - \\
\hline HBO sociaal-cultureel & 97 & 95 & 84 \\
\hline HBO kunst & 24 & - & 80 \\
\hline HBO politie en defensie & - & - & 85 \\
\hline WO letteren & 98 & - & 82 \\
\hline WO theologisch & - & - & - \\
\hline WO landbouw en milieukunde & - & - & 83 \\
\hline WO wiskunde en natuurwetenschappen & 71 & 100 & 82 \\
\hline WO (weg-en water)bouwkunde & 92 & - & - \\
\hline WO werktuigbouwkunde & - & - & - \\
\hline WO elektrotechniek en technische informatica & 91 & - & - \\
\hline WO dier-, genees- en tandheelkunde & 96 & - & 94 \\
\hline WO farmacie & - & - & - \\
\hline WO econom(etr)ie en accountancy & 92 & 94 & - \\
\hline WO bedrijfskunde & - & - & - \\
\hline WO informatica & - & - & - \\
\hline WO juridisch & 96 & 93 & 92 \\
\hline WO bestuurlijk & 98 & - & - \\
\hline WO sociaal-cultureel & 99 & 96 & 88 \\
\hline WO kunst & 80 & - & - \\
\hline
\end{tabular}

Tabel 5.3 gaat in op de vereiste managementvaardigheden. Over het algemeen is de behoefte aan managementvaardigheden groter in het gedeelde domein dan in het uitwijkdomein of het vakspecifieke domein. In het vakspecifieke domein is vooral bij $\mathrm{HBO}$ haven en vervoer de behoefte aan managementkwaliteiten groot. Verder valt op dat voor $\mathrm{HBO}$ sociaal-cultureel in het gedeeld domein veelal managementvaardigheden zijn vereist. Afgezien van $\mathrm{HBO}$ onderwijs, HBO elektrotechniek en technische informatica, $\mathrm{HBO}$ bedrijfsinformatica, $\mathrm{HBO}$ en technische bedrijfskunde zijn management vaardigheden in het gedeeld domein altijd redelijk belangrijk. De genoemde uitzonderingen komen voor een groot deel voort uit het beroep programmeur of systeemanalist dat in het gedeelde segment is ingedeeld, maar geen managementvaardigheden vereist. In het uitwijkdomein zijn deze vaardigheden met name van belang voor HBO politie en defensie. 
Zoals verwacht kon worden blijken communicatieve vaardigheden vrijwel overal, omgeacht het domein van groot belang. Tabel 5.4 geeft hiervan een overzicht. $\mathrm{Er}$ zijn slechts twee duidelijke uitzonderingen. Bij $\mathrm{HBO}$ technisch laboratorium en bij HBO kunst zijn deze 'people skills' in het vakspecifieke domein van slechts geringe betekenis. Ook voor $\mathrm{HBO}$ haven en vervoer en $\mathrm{HBO}$ medisch laboratorium komt in het eigen domein dit belang niet hoger dan ongeveer $50 \%$.

Tabel 5.5

Algemene vaardigheden vereist op vakspecifiek en uitwijksegment

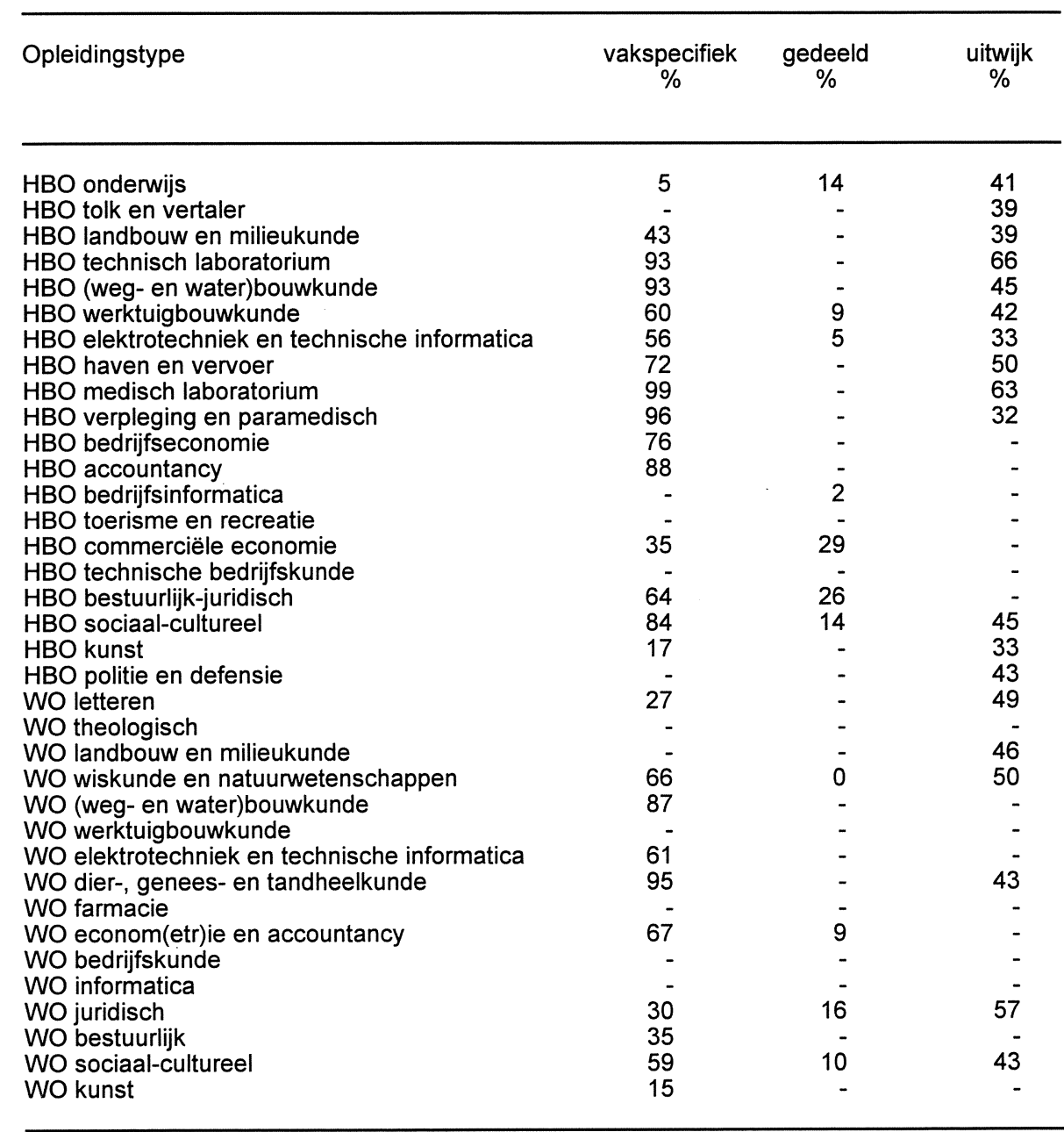

Tot slot van deze analyse wordt in tabel 5.5 ingegaan op het belang van algemene vaardigheden, zoals oplettendheid en ruimtelijk voorstelingvermogen. Extreme scores op dit gebied bevinden zich vooral in het vakspecifieke domein. Meer dan $80 \%$ score wordt hier gevonden bij $\mathrm{HBO}$ en WO (weg- en water)bouwkunde, HBO werktuigbouwkunde, $\mathrm{HBO}$ medisch laboratorium, $\mathrm{HBO}$ verpleging en paramedisch, 
HBO accountancy en bij WO dier-, genees-, en tandheelkunde. Een lage behoefte aan algemene vaardigheden wordt aangetroffen bij HBO onderwijs in het vakspecifiek domein en een groot aantal richtingen in het gedeelde domein. 
$\ldots \ldots$ 


\section{Toepassingsmogelijkheden binnen het informatiesysteem onderwijs-arbeidsmarkt}

Als afsluiting van dit rapport zal in dit hoofdstuk nader worden ingegaan op de mogelijkheden om de informatie over de verschillende aspecten van het beroependomein van opleidingstypen op te nemen in het ROA-informatiesysteem onderwijs-arbeidsmarkt. Tevens zal worden aangegeven wat de gebruikswaarde van deze informatie kan zijn voor enkele mogelijke gebruikersgroepen.

Zoals reeds in hoofdstuk 1 werd aangestipt zijn er in principe twee inpassingsmogelijkheden voor de aanvullende informatie die er gegeven kan worden over de verschillende beroependomeinen. In de eerste plaats kan er actuele informatie worden gegeven over de onderzochte kenmerken van de inhoud van het werk, verbijzonderd naar beroepsgroep en opleidingstype. In de tweede plaats kunnen de getraceerde karakteristieken van beroepen worden gerelateerd aan de prognoses van de vraagontwikkelingen op de arbeidsmarkt. Op deze wijze kan inzicht worden verkregen in de implicaties van de verwachte verschuivingen in de beroepenstructuur van de werkgelegenheid voor de verschuivingen in de vereiste vaardigheden, de fysieke belasting e.d. voor de afgestudeerden van de diverse opleidingstypen.

Actuele informatie over de inhoud van het werk

In de voorgaande hoofdstukken is vanuit een vijftal invalshoeken getracht de inhoud van het werk nader te karakteriseren. Daarbij ging de aandacht uit naar het beroepsniveau, het beroepsterrein, de vereiste vaardigheden, de aard van de werkzaamheden en twee aspecten van de kwaliteit van het werk: de fysieke belasting en de kans op buitenwerk. In principe zou de aanvullende informatie op dit punt kunnen worden gepresenteerd naar bedrijfssector, beroepsgroep en opleidingstype.

Naar bedrijfssector zal de informatie waarschijnlijk met name van waarde kunnen zijn op beleidsniveau. Daarbij zal het doorgaans vooral gaan om een algehele typering van de verschillende bedrijfssectoren op basis van geaggregeerde cijfers, waarmee de bedrijfssectoren ten opzichte van elkaar gepositioneerd kunnen worden. Op deze wijze kan bijvoorbeeld worden aangegeven in welke sectoren de fysieke belasting die de werkzaamheden met zich meebrengen het hoogst is, of wat het relatieve belang is van de vereiste vaardigheden in de verschillende bedrijfssectoren.

Vanzelfsprekend kan ook nadere informatie worden gegeven over de verschillende aspecten van de inhoud van het werk naar beroepsgroep. Voor wat betreft de 
informatie over het beroepsniveau en het beroepsterrein is er een overlap met de beoogde informatieve waarde van de huidige tabel met betrekking tot de belangrijkste opleidingstypen per beroepsklasse (Statistische Bijlage, tabel 2.10). De in dit rapport ontwikkelde typeringen vallen deze veelheid aan informatie echter samen, waardoor een duidelijker beeld kan ontstaan. Op de overige punten zal de informatie voorlichtende waarde kunnen hebben voor de studie- en beroepskeuze.

Zoals reeds eerder werd opgemerkt lag de primaire doelstelling van deze studie niet bij het typeren van beroepen, maar bij het in beeld brengen van de mogelijkheden deze informatie over de inhoud van het werk van de verschillende beroepen te gebruiken om meer inzicht te geven in het werkveld van de afgestudeerden naar opleidingstype. Daarbij kan in de eerste plaats worden gedacht aan directe informatie over de in beeld gebrachte kenmerken van het werk per opleidingstype, min of meer in de vorm van de in hoofdstuk 4 gepresenteerde tabellen:

- de werkgelegenheid naar beroepsniveau;

- de werkgelegenheid naar beroepsterrein;

- de belangrijkste werksoorten in het werkveld van de afgestudeerden;

- de vereiste vaardigheden in het werkveld;

- de kans op fysiek belastend werk;

- de kans op een beroep met buitenwerk.

Wellicht is het wenselijk om de informatie over het beroepsniveau te transformeren in informatie over het percentage werkenden dat werk heeft op een strikt bij de gevolgde opleiding aansluitend niveau, een lager niveau, een hoger niveau, of een ruimer gedefinieerd beroepsniveau. Deze aanpak is ook gevolgd door De Grip, Borghans en Smits (1996), de bij het in beeld brengen van het beroepsniveau van het werkveld van hoger opgeleiden het onderscheid maken tussen functies op HBOniveau, functies op universitair niveau, functies op een lager niveau (MBO of lager) en functies op hoger niveau (het gedeelde domein van HBO- en WO-opleidingen). Deze informatie over de inhoud van het werk naar opleidingstype zou met name voorlichtende waarde kunnen hebben voor de studie- en beroepskeuzevoorlichting. De informatie over de fysieke belasting - eventueel te verbijzonderen naar meerdere aandachtspunten - is een goed voorbeeld van de arbeidsmarktinformatie die waardevol zou kunnen zijn voor de studie- en beroepskeuzevoorlichting ten behoeve van lichamelijk gehandicapten.

In de tweede plaats kan, zoals in hoofdstuk 5 werd aangegeven, per opleidingstype informatie worden gegeven over de relatie tussen de verschillende kenmerken van het beroepsdomein. Naast de in hoofdstuk 5 beschreven informatie over de vereiste vaardigheden en de fysieke belasting op het vakspecifieke domein en het uitwijkdomein van de afgestudeerden met een bepaalde opleidingsachtergrond, kan daarbij ook gedacht worden aan de te verrichten werksoorten en de kans op buitenwerk op het vakspecifieke en het uitwijkdomein. Op soortgelijke wijze kan 
informatie worden verstrekt over de werksoorten, vereiste vaardigheden, fysieke belasting en de kans op buitenwerk bij functies die aansluiten bij het gevolgde opleidingsniveau en de functies op een lager of hoger niveau. De informatie over de te verrichten werksoorten en de daarvoor te vereiste vaardigheden zou in principe in het vakspecifieke en uitwijkdomein van een bepaald opleidingstype zou, in combinatie met de informatie over de arbeidsmarktpositie van het desbetreffende opleidingstype een signaalwerking kunnen hebben voor de curriculumplanning. De informatie over de werksoorten en de fysieke belasting in het vakspecifieke en uitwijkdomein kan met name waardevol zijn voor het in beeld brengen van de herintredemogelijkheden van vooormalig arbeidsongeschikten. Indien er bijvoorbeeld bij een bepaald opleidingstype sprake is van een omvangrijk uitwijkdomein waarvoor, in tegenstelling tot het vakspecifieke segment, de fysieke belasting gering is, zou hieruit kunnen worden afgeleid dat arbeidsongeschikten met de desbetreffende opleidingsachtergrond die voor hun herintrede zijn aangewezen op werk dat een geringe fysieke belasting met zich meebrengt, zich niet zouden hoeven om te scholen.

In de derde plaats zou de informatie over de verschillende aspecten van de inhoud van het werk ook kunnen worden verbijzonderd naar geslacht of leeftijdsgroep. Daarbij kan ook gedacht worden aan het vergelijken van de inhoud van het werk van schoolverlaters met de totale werkzame bevolking met de desbetreffende opleidingsachtergrond. Een dergelijke vergelijking zou kunnen worden gemaakt door de beroepenspreiding zoals die wordt waargenomen in de de RUBS-enquête en HBO-Monitor af te zetten tegen de beroepsdomeinen van de werkenden met de desbetreffende opleidingsachtergrond in de EBB.

Prognoses met betrekking tot de inhoud van het werk

In De Grip, Borghans en Smits (1996) wordt een voorbeeld gegeven van de mogelijkheden de informatie over de inhoud van het werk te relateren aan de prognoses van de werkgelegenheidsontwikkkeling voor de verschillende opleidingstypen. Zij richten zich daarbij op het in beeld brengen van de verwachte verschuivingen in het beroepsniveau en het beroepsdomein van de werkgelegenheid van hoger opgeleiden. Op dezelfde wijze kunnen ook de gevolgen van de te verwachten verschuivingen in de beroepenstructuur van de werkenden met een bepaalde opleidingsachtergrond voor de te verrichten werksoorten, de vereiste vaardigheden, de fysieke belasting en de kans op buitenwerk in beeld worden gebracht.

Bovendien maakt, zoals de analyses van De Grip, Borghans en Smits (1996) laten zien, de huidige prognosemethodiek het ook mogelijk om de implicaties van goede of slechte arbeidsmarkt-perspecten voor de verschillende aspecten van de inhoud van het werk in beeld te brengen. Zo kan bijvoorbeeld worden aangegeven in 
hoeverre een ex ante aanbodoverschot kan leiden tot een toename van de werkgelegenheid op een lager opleidingsniveau of een toename van het fysiek belastend werk.

De gebruiksmogelijken van deze prognoses liggen op hetzelfde vlak als bij de actuele informatie over de inhoud van het werk. De informatie zou in de eerste plaats de betekenis van de arbeidsmarktprognoses voor de studie- en beroepskeuze nog kunnen doen toenemen, waarbij de informatie over de te verrichten werksoorten en de fysieke belasting met name waardevol zou kunnen zijn bij de voorlichting van lichamelijk gehandicapten. De informatie over de verwachte ontwikkelingen van de te verrichten werksoorten en de vereiste vaardigheden als gevolg van de voorspelde verschuivingen in het beroependomein van opleidingen zal in combinatie met de informatie over de arbeidsmarktperspectieven van de afgestudeerden met name waardevol zijn voor de curriculumplanning.

\section{Verdere ontwikkelingsmogelijkheden}

In hoofdstuk 2 werd aangegeven dat de 'empirische methode' de voorkeur verdient bij het in beeld brengen van de inhoud van het werk, omdat op deze wijze actuele informatie wordt verstrekt en bovendien rekening gehouden wordt met het feit dat de inhoud van het werk mede bepaald wordt door de schaarsteverhoudingen op de arbeidsmarkt. Bij de in dit rapport beschreven indicatoren is alleen het beroepsniveau en het beroepsterrein volgens deze aanpak vastgesteld. De andere indicatoren, die direct of indirect uit de SBC'92 zijn afgeleid, zijn allemaal gebaseerd op expert-oordelen, die zoals gezegd als belangrijk nadeel hebben dat ze snel kunnen zijn verouderd en bovendien geen rekening houden met een mogelijke heterogeniteit binnen een bepaald beroep.

Dit maakt het wenselijk bij deze dimensies van de inhoud van het werk meer gebruik te maken van subjectieve oordelen van de werkende zelf. Daarbij zou in de toekomst gebruik gemaakt kunnen worden van de informatie over diverse aspecten van de kwaliteit van het werk, die uit de EBB en het Doorlopend Leefsituatieonderzoek van het CBS kan worden gegenereerd. Dit biedt bovendien de mogelijkheid om veel meer gedetailleerde informatie te geven over een aantal specifieke aspecten van de aard van het werk die relevant zijn voor de fysieke en geestelijke belasting van de werkenden (zie paragraaf 3.6). Het opnemen van deze informatie over de actuele inhoud van het werk en de verwachte verschuivingen daarin, zou de betekenis van de informatie voor de studie- en beroepskeuzevoorlichting aan gehandicapten en de herintegratieproblematiek van arbeidsongeschikten in belangrijke mate kunnen doen toenemen. Daarbij zou ook een vergelijking kunnen worden gemaakt van het imago van het beroependomein van een bepaalde opleidngsrichting onder jongeren, die voor een studiekeuzebeslissing staan (zie bijvoorbeeld Willems en De Grip, 1993). Wel moet 
daarbij bedacht worden dat de prognoses op dit punt alleen de verwachte verschuivingen in de fysieke en geestelijke belasting van de werkenden met een bepaalde opleidingsachtergrond in beeld brengen, voor zover dit een gevolg is van verschuivingen in het beroependomein van het desbetreffende opleidingstype. Nagegaan zou moeten worden op welke wijze daarnaast ook rekening gehouden zou kunnen worden met de te verwachten verschuivingen in de lichamelijke en geestelijke belasting binnen een bepaald beroep.

Op soortgelijke wijze zou ook gebruik gemaakt kunnen worden van subjectieve informatie over de vereiste vaardigheden, kennis en technieken die beschikbaar is in de RUBS-enquête en de HBO-monitor ${ }^{4}$. Op deze wijze kan een gedetailleerd beeld worden verkregen van de betekenis van diverse kennis- en vaardigheidsaspecten in de beroepsdomeinen van de schoolverlaters met een bepaalde opleidingsachtergrond, met een eventuele verbijzondering naar het vakspecifieke domein en het uitwijkdomein. Een voorbeeld hiervan is te vinden in Borghans, De Grip en Smits (1995, p. 43), waarin de vereiste vaardigheden in de vaktechnische beroepen en de niet-technische beroepen van de afgestudeerden van het Hoger Technisch Onderwijs met elkaar worden vergeleken.

4. In de RUBS-enquête wordt deze informatie alleen verzameld voor de MBO-schoolverlaters. 


\section{Literatuur}

Becker G.S. (1964) Human Capital; A Theoretical and Empirical Analysis with Special Reference to Education, New York, National Bureau of Economic Research.

Benders, M., J. Kiezebank, M. Reiche, E. Zelm (1986), Onderzoeksresultaten herfundering beroepenkundige theorie en methodiek fase I, Bakkenist, Spits en co.

Bishop, J. (1995), Expertise and Excellence, Working Paper 95-13, Cornell University, Ithaca, NY.

Borghans, L. (1993), Educational Choice and Labour Market Information. Proefschrift, Maastricht

Borghans, L., A. de Grip, W. Smits (1995), Beroepsmobiliteit van technisch opgeleiden, OSA D1.

CBS (1993), Standaard Beroepenclassificatie 1992, Sdu/uitgeverij, Den Haag.

Grip, A. de (1995), Betekenis SBC'92 voor onderwijs-arbeidsmarktonderzoek, in: B.F.M. Bakker, J.A. Oud (red.) Beroepenclassificaties, luwe of noodzaak?, Centraal Bureau voor de Statistiek, Voorburg, pp. 38-41.

Grip, A. de, L. Borghans, W. Smits (1997), Future developments in the job level and domain of highly-skilled workers, in: Heijke, H. en L. Borghans (eds.), Towards a Transparent Labour Market for Educational Decisions, Avebury, United Kingdom.

Groeneveld, S.M. (1996), Het meten van overscholing, ESB, 4061, p. 511.

Hartog J. (1985) Earnings Functions; Testing for the Demand Side, Economic Letters, vol. 19, p. 281-285.

Hartog, J., N. Jonker (1997), A Job to Match your Education: Does it Matter?, in: Heijke, H. en L. Borghans (eds.), Towards a Transparent Labour Market for Educational Decisions, Avebury, United Kingdom.

Heijke, J.A.M. (1993), Towards a Transparent Labour Market for Training Decisions, in: Europe's Human Resources in the 1990's, Reports from the 1993 Cumberland Lodge Conference, prepared by TARGET with support from the European Commission, Task Force Human Resources, Education, Training and Youth, pp. 60-75.

Huygen, F. (1989), De kwalitatieve structuur van de werkgelegenheid in Nederland, deel III, OSA-V33, Den Haag.

Oosterbeek, H., D. Webbink (1995), Enrolment in higher education in the Netherlands, De Economist, vol. 143 , no. 3, pp. 367-380.

ROA (1995a), De arbeidsmarkt naar opleiding en beroep tot 2000, ROA-R-1995/3, Maastricht.

ROA (1995b), De arbeidsmarkt naar opleiding en beroep tot 2000. Statistische bijlage, ROA-R1995/3B, Maastricht.

Schultz, T.W. (1961), Investment in Human Capital, American Economic Review, pp. 1-17.

Spence M. (1974) Market Signaling, Harvard University Press, Cambridge.

Tinbergen J. (1956) On the Theory of Income Distribution, Weltschaftliches Archiv, vol. 77, no. 2, p.155-175.

Verdugo, R., N. Verdugo (1989), The impact of surplus schooling on earnings: some additional findings, Journal of Human Resources, vol. 24, pp. 629-643.

Weerdenburg, L.J.M. (1985), Studiekeuze en studievoorlichting; Een onderzoek onder 5e klas VWO-leerlingen in Oost-Nederland. Faculteit Bestuurskunde, Universiteit Twente. 
Wieling, M., L. Borghans (1995), Discrepancies between Demand and Supply and Adjustment Processes on the Labour Market, ROA-RM-1995/4E, Maastricht.

Willems, E.J.T.A., A. de Grip (1993), Jongeren en techniek. Studie- en beroepskeuzes, waardering en beeldvorming ten aanzien van techniek, Ministerie van Economische Zaken, Beleidstudies Technologie Economie, no. 26, Den Haag.

Winkel, J.A.W. de (1990) Handboek functie-inhoud-typering (FIT). Beroepenapplicatie PGI, CBA, Rijswijk. 


\section{Bijlage A Typeringen van de werksoorten SBC '92}

Tabel A.1

Indeling in niet-fysieke en fysieke werksoorten

\begin{tabular}{|c|c|c|}
\hline Werksoort & Niet-fysiek & Fysiek \\
\hline 1 leidinggeven aan leidinggevenden en beleidvoeren & $x$ & \\
\hline 2 leidinggeven aan uitvoerenden en beleidvoeren & $x$ & \\
\hline 3 leidinggeven aan uitvoerenden zonder beleidvoeren & $\mathrm{x}$ & \\
\hline 4 beleid voeren zonder leidinggeven & $x$ & \\
\hline 5 beleid voerbereiden & $x$ & \\
\hline 6 werkvoorbereiden, werk coordineren & $x$ & \\
\hline 7 calculeren & $x$ & \\
\hline 8 inspecteren & $x$ & \\
\hline 9 adviseren; juridisch, fiscaal & $\mathrm{x}$ & \\
\hline 10 adviseren; organisatorisch & $x$ & \\
\hline 11 adviseren; commercieel, economisch & $x$ & \\
\hline 12 adviseren; technisch, technologisch & $x$ & \\
\hline 13 adviseren; sociaal, maatschappelijk & $x$ & \\
\hline 14 voorlichten, informeren & $x$ & \\
\hline 15 onderzoeken; niet cijfermatig & $x$ & \\
\hline 16 onderzoeken; cijfermatig & $x$ & \\
\hline 17 analistenwerk & $x$ & \\
\hline 18 controleren, testen, sorteren & $x$ & \\
\hline 19 schrijven, redigeren, vertalen & $x$ & \\
\hline 20 informatica ontwikkelen, adviseren & $x$ & \\
\hline 21 informatica beheren, verwerken & $x$ & \\
\hline 22 ontwerpen, construeren & $x$ & \\
\hline 23 technisch tekenen, berekenen, meten & $x$ & \\
\hline 24 personeelswerk verrichten & $x$ & \\
\hline 25 secretarieel werk verrichten & $x$ & \\
\hline 26 administreren; cijfermatig & $x$ & \\
\hline 27 administreren; toetsen aan regels & $x$ & \\
\hline 28 administreren; teksten & $x$ & \\
\hline 29 typen, tekstverwerken & $x$ & \\
\hline 30 archief-, bibliotheekwerk verrichten & $x$ & \\
\hline 31 verrichten kantoor-hulpwerkzaamheden & $x$ & \\
\hline 32 ontvangen, informeren & $x$ & \\
\hline 33 handel drijven in het groot & $x$ & \\
\hline 34 inkopen & $x$ & \\
\hline 35 verkopen; vertegenwoordigen & $x$ & \\
\hline 36 verkopen(excl.vertegenwoordigen) & $x$ & \\
\hline 37 afrekenen & $x$ & \\
\hline 38 opslaan, uitgeven & & $x$ \\
\hline 39 laden, lossen & & $x$ \\
\hline 40 bezorgen & & $x$ \\
\hline
\end{tabular}


Tabel A.1 (vervolg)

Indeling in niet-fysieke en fysieke werksoorten

41 transporteren, sjouwen

42 mobiele machines, kranen bedienen

43 besturen vliegtuig

44 besturen vaartuig

45 besturen railvoertuig

46 besturen vrachtauto

47 besturen autobus

48 besturen personenauto, bestelauto

49 bewaken, beveiligen, toezicht houden

50 schoonmaken huishoudelijk, kantoor

51 schoonmaken, industrieel reinigen

52 smelten, vormen, gieten

53 verspanen

54 bankwerken

55 gereedschapmaken, fijnbankwerken, instrumentmaken

56 plastisch vormgeven

57 plaatwerken

58 lassen, snijden, solderen

59 isoleren

60 monteren: leidingen (installatietechniek)

61 monteren: constructies

62 monteren, samenbouwen: machines, apparaten

63 monteren, repareren: mechanisch

64 onderhouden, repareren: (motor-)voertuigen

65 monteren, repareren: sterkstroom

66 monteren, repareren: zwakstroom

67 monteren, repareren: elektronica

68 metselen, voegen, tegelzetten

69 stukadoren

70 beton-, betonstaalwerk verrichten

71 timmeren

72 machinaal houtbewerken

73 vloerbedekken, stofferen

74 schilderen, verven, spuiten

75 glaszetten, glassnijden

76 dakdekken

77 onderhoudswerk: timmeren, metselen, glaszetten

78 onderhoudswerk: elektrische installaties

79 onderhoudswerk: gas-, water-, verwarmingsinstallaties

80 straatmaken, grondwerken

81 drukvoorbereiden: tekst

82 drukvoorbereiden: beeld

83 drukken

84 grafisch nabewerken

85 confectiewerk verrichten, kleermaken

86 leder bewerken

87 snijden, slachten 
Tabel A.1 (vervolg)

Indeling in niet-fysieke en fysieke werksoorten

\begin{tabular}{|c|c|c|}
\hline Werksoort & Niet-fysiek & Fysiek \\
\hline 88 voedsel bereiden (niet kant en klaar) & & $x$ \\
\hline 89 voedsel bereiden (kant en klaar) & $x$ & \\
\hline 90 serveren & & $x$ \\
\hline 91 produktiemachines, -apparatuur bedienen & & $x$ \\
\hline 92 produktiemachines instellen, ombouwen & & $x$ \\
\hline 93 produktieprocessen bewaken & $x$ & \\
\hline 94 samenstellen, assembleren & & $x$ \\
\hline 95 inpakken, verpakken (handmatig) & & $x$ \\
\hline 96 slopen & & $x$ \\
\hline 97 demonteren & & $x$ \\
\hline 98 ambachtelijk vervaardigen, repareren & & $x$ \\
\hline 99 les geven, doceren & $x$ & \\
\hline 100 training geven (fysiek) & & $x$ \\
\hline 101 genezen mensen & $x$ & \\
\hline 102 geneskundig assisteren: technisch & $x$ & \\
\hline 103 geneeskundig assisteren: niet technisch & $x$ & \\
\hline 104 steriliseren & $x$ & \\
\hline 105 therapeutisch begeleiden (fysiek) & & $x$ \\
\hline 106 agogisch, maatschappelijk begeleiden & $x$ & \\
\hline 107 verplegen & & $x$ \\
\hline 108 verzorgen, helpen mensen & & $x$ \\
\hline 109 verzorgen uiterlijk & $x$ & \\
\hline 110 dieren genezen & $x$ & \\
\hline 111 diergneeskundig assisteren & $x$ & \\
\hline 112 dieren verzorgen, africhten & $x$ & \\
\hline 113 jagen, ongedierte bestrijden & & $x$ \\
\hline 114 tuinbouwwerk verrichten & & $x$ \\
\hline 115 hovenierswerk verrichten & & $x$ \\
\hline 116 landbouwwerk verrichten (excl. veeteelt) & & $x$ \\
\hline 117 veeteeltwerk verrichten & & $x$ \\
\hline 118 bosbouwwerk verrichten & & $x$ \\
\hline 119 visserijwerk verrichten & & $x$ \\
\hline 120 beeld-,geluids-,zend-, belichtingsapparatuur bedienen & $x$ & \\
\hline 121 acteren, regisseren & & $\mathbf{x}$ \\
\hline 122 tentoonstellen, presenteren programma's & & $x$ \\
\hline 123 presenteren uiterlijk & & $x$ \\
\hline 124 dansen & & $x$ \\
\hline 125 zingen & & $x$ \\
\hline 126 musiceren, dirigeren, componeren & & $x$ \\
\hline 127 beeldende kunst beoefenen & $x$ & \\
\hline 128 sport beoefenen & & $x$ \\
\hline
\end{tabular}


Tabel A.2

Indeling van werksoorten in binnen- en buitenwerk

Werksoort

Binnen Binnen/Buiten Buiten

1 leidinggeven aan leidinggevenden en beleidvoeren

2 leidinggeven aan uitvoerenden en beleidvoeren

3 leidinggeven aan uitvoerenden zonder beleidvoeren

4 beleid voeren zonder leidinggeven

5 beleid voerbereiden

6 werkvoorbereiden, werk coordineren

7 calculeren

8 inspecteren

9 adviseren; juridisch, fiscaal

10 adviseren; organisatorisch

11 adviseren; commercieel, economisch

12 adviseren; technisch, technologisch

13 adviseren; sociaal, maatschappelijk

14 voorlichten, informeren

15 onderzoeken; niet cijfermatig

16 onderzoeken; cijfermatig

17 analistenwerk

18 controleren, testen, sorteren

19 schrijven, redigeren, vertalen

20 informatica ontwikkelen, adviseren

21 informatica beheren, verwerken

22 ontwerpen, construeren

23 technisch tekenen, berekenen, meten

24 personeelswerk verrichten

25 secretarieel werk verrichten

26 administreren; cijfermatig

27 administreren; toetsen aan regels

28 administreren; teksten

29 typen, tekstverwerken

30 archief-, bibliotheekwerk verrichten

31 verrichten kantoor-hulpwerkzaamheden

32 ontvangen, informeren

33 handel drijven in het groot

34 inkopen

35 verkopen; vertegenwoordigen

36 verkopen(excl.vertegenwoordigen)

37 afrekenen

38 opslaan, uitgeven

39 laden, lossen

40 bezorgen

41 transporteren, sjouwen

42 mobiele machines, kranen bedienen

$x$

$x$

$x$

$x$

$x$

$x$

$x$

$x$

$x$

$x$

$x$

$x$

$x$

$x$

$x$

$x$

$x$

$x$

$x$
$x$

43 besturen vliegtuig

44 besturen vaartuig

45 besturen railvoertuig

46 besturen vrachtauto

47 besturen autobus $x$

$x$ 
Tabel A.2 (vervolg)

Indeling van werksoorten in binnen- en buitenwerk

Werksoort

Binnen Binnen/Buiten Buiten

48 besturen personenauto, bestelauto

49 bewaken, beveiligen, toezicht houden

$x$

50 schoonmaken huishoudelijk, kantoor

51 schoonmaken, industrieel reinigen

$x$

52 smelten, vormen, gieten

53 verspanen

54 bankwerken

$x$

55 gereedschapmaken, fijnbankwerken, instrumentmaken

56 plastisch vormgeven

57 plaatwerken

58 lassen, snijden, solderen

59 isoleren

60 monteren: leidingen (installatietechniek)

61 monteren: constructies

62 monteren, samenbouwen: machines, apparaten

63 monteren, repareren: mechanisch

64 onderhouden, repareren: (motor-)voertuigen

65 monteren, repareren: sterkstroom

66 monteren, repareren: zwakstroom

67 monteren, repareren: elektronica

68 metselen, voegen, tegelzetten

69 stukadoren

70 beton-, betonstaalwerk verrichten

71 timmeren

72 machinaal houtbewerken

73 vloerbedekken, stofferen

74 schilderen, verven, spuiten

75 glaszetten, glassnijden

76 dakdekken

77 onderhoudswerk: timmeren, metselen, glaszetten

78 onderhoudswerk: elektrische installaties

79 onderhoudswerk: gas-, water-, verwarmingsinstallaties $x$

80 straatmaken, grondwerken

81 drukvoorbereiden: tekst

82 drukvoorbereiden: beeld

83 drukken

84 grafisch nabewerken

85 confectiewerk verrichten, kleermaken

86 leder bewerken

87 snijden, slachten

88 voedsel bereiden (niet kant en klaar)

89 voedsel bereiden (kant en klaar)

90 serveren

91 produktiemachines, -apparatuur bedienen $\quad \mathrm{x}$

92 produktiemachines instellen, ombouwen $\quad x$

93 produktieprocessen bewaken

94 samenstellen, assembleren

\section{$x$}

$x$

$x$ 
Tabel A.2 (vervolg)

Indeling van werksoorten in binnen- en buitenwerk

Werksoort Binnen Binnen/Buiten Buiten

95 inpakken, verpakken (handmatig)

96 slopen

97 demonteren

98 ambachtelijk vervaardigen, repareren

99 les geven, doceren

100 training geven (fysiek)

101 genezen mensen

102 geneskundig assisteren: technisch

103 geneeskundig assisteren: niet technisch

104 steriliseren

105 therapeutisch begeleiden (fysiek)

106 agogisch, maatschappelijk begeleiden

107 verplegen

108 verzorgen, helpen mensen

109 verzorgen uiterlijk

110 dieren genezen

111 diergneeskundig assisteren

112 dieren verzorgen, africhten

113 jagen, ongedierte bestrijden

114 tuinbouwwerk verrichten

115 hovenierswerk verrichten

116 landbouwwerk verrichten (excl. veeteelt)

117 veeteeltwerk verrichten

118 bosbouwwerk verrichten

119 visserijwerk verrichten

120 beeld-,geluids-,zend-, belichtingsapparatuur bedienen $x$

121 acteren, regisseren

122 tentoonstellen, presenteren programma's

123 presenteren uiterlijk

$\mathbf{x}$

$x$

$x$

$x$

$x$

$x$

$x$

$x$

$x$

$x$

$x$

$x$

$\mathbf{x}$

$x$

$x$

125 zingen

126 musiceren, dirigeren, componeren

127 beeldende kunst beoefenen

128 sport beoefenen $x$

$x$

$x$

$\begin{array}{ll} & \mathrm{x} \\ & \mathrm{x} \\ & \mathrm{x} \\ & \mathrm{x} \\ & \mathrm{x} \\ & \mathrm{x} \\ & \\ & \\ & \\ & \\ & \\ & \\ & \end{array}$

